\title{
Weathering of the primary rock-forming minerals: processes, products and rates
}

\author{
M. J. WILSON \\ The Macaulay Institute, Craigiebuckler, Aberdeen AB15 8QH, UK
}

(Received 3 April 2004; revised 26 May 2004)

\begin{abstract}
This paper describes the ways in which the major rock-forming primary minerals (olivine, pyroxenes, amphiboles, feldspars, micas and chlorites) break down during weathering, the products that develop during this breakdown and the rates at which this breakdown occurs. The perspective chosen to illustrate this vast topic is that of the residual soil weathering profile. Different physical and chemical conditions characterize the various parts of such a profile. Thus, in the slightly weathered rock at the base of the profile, mineral weathering will take place in microfissures and narrow solution channels and the capillary water in such spatially restricted volumes may be expected to be close to equilibrium with the primary mineral. In these circumstances, the weathering product formed may be closely related to the primary mineral both compositionally and structurally. The saprolite higher up in the weathering profile may or may not retain the fabric and structure of the original parent rock, but in either case the close relationship observed between primary mineral and weathering product in the slightly weathered rock may be lost. This part of the profile will usually be affected by freely flowing drainage waters, the composition of which will be far from equilibrium with specific primary minerals. Weathering products which do form are likely to reflect the interaction between bulk water and bulk parent material. In the soil profile, the situation will be further complicated by organic ligands derived from decomposing organic matter or from the direct activities of soil microbes or plant roots. Thus, biological weathering will assume a much greater significance in this part of the profile compared with the mainly inorganic processes dominating in the saprolite and the slightly weathered rock. The general nature of any particular weathering profile will reflect the interactions between climate, topography, parent material, soil biota and time and superimposed upon this complexity, when considering how individual primary minerals break down in detail, will be factors related to the nature of the mineral itself. Particularly important in this respect is the inherent susceptibility of the mineral to weathering, which is related to overall chemical composition and structure, as well as the distribution and density of defects, dislocations and exsolution features, which often control the progress of the weathering reaction.
\end{abstract}

KEYWORDS: weathering, olivine, pyroxene, amphibole, feldspar, biotite, muscovite, chlorite, soil, saprolite.

Weathering is a fundamental process in the geological cycle that should be regarded as of equal importance as the processes of metamorphism, volcanism, diagenesis, erosion, etc., that are much more extensively studied in most departments of earth science. Indeed, a case could be made for mineral weathering to be considered as

* E-mail: j.wilson@macaulay.ac.uk

DOI: $10.1180 / 0009855043930133$ the most important process in the geological cycle as it most directly affects the living world in general and the life of man in particular. Thus, weathering is responsible for the formation of soils, upon which nearly all terrestrial life ultimately depends, playing a central role in controlling the inherent fertility status of soils through the supply of many of the nutrients that enable plants to grow. Again, in more recent times it has been realized that mineral weathering acts as a buffer against a variety 
of environmental threats that are of direct concern to man. For example, the impact of acid deposition on the terrestrial environment is mediated to a large extent by the primary mineral content of the soil (Nilsson and Grennfelt, 1988). If the soil contains few weatherable minerals then incoming acidic deposition from the atmosphere will not be neutralized by basic cations from soil minerals and acidification of the soil will ensue, leading to undesirable changes in the terrestrial ecosystem dependent on the soil (Sverdrup et al., 1994). Furthermore, this acidity in the form of dissolved protonated $\mathrm{Al}$ ions may then be transferred from the soil to surface waters, in turn causing their acidification and resulting in undesirable impacts on the aquatic ecosystem (Sverdrup and Warfvinge, 1990). On the other hand, a soil may not be sensitive to the impact of acid deposition because it contains an adequate supply of weatherable baserich primary minerals and is able to effectively neutralize the incoming acidity. Mineralogy and weathering rates are therefore crucial in determining whether or not a soil is sensitive to the effects of acid deposition from the atmosphere. This has been taken into account in the application of the critical loads concept to the effects of acid deposition (Sverdrup et al., 1990), and is now the basis for determining the acceptable limits of acid emissions to the atmosphere in many countries (Hettelingh et al., 1991).

Mineral weathering also helps to protect the environment, directly or indirectly, from a variety of other threats. It is of direct importance, for example, in the problem of climate change, certainly on a geological time scale. Thus a direct negative feedback relationship has been proposed (Berner, 1991) between increasing atmospheric $\mathrm{CO}_{2}$ levels and weathering rates of $\mathrm{Ca}$-bearing silicate minerals like plagioclase feldspars, pyroxenes and amphiboles. The increasing Earth surface-temperatures resulting from the greenhouse effect of higher atmospheric $\mathrm{CO}_{2}$ levels will also cause accelerated weathering rates through higher rainfall and run-off, the calcium so removed being converted to $\mathrm{CaCO}_{3}$ by reaction with $\mathrm{CO}_{2}$ in the atmosphere, thus acting as an effective sink for this gas. According to Walker et al. (1981) and Berner (1991), in these circumstances the long-term effect of geochemical weathering is to stabilize global surface temperatures.

Mineral weathering may also exert an indirect protective effect on the environment. For example, some heavy metals and radioactive elements may be preferentially adsorbed or fixed in the soil by certain clay or $\mathrm{Fe}$ oxide minerals, which are themselves the products of primary mineral weathering. These pollutants are thus made less available for uptake by plants or are inhibited from being dispersed into the wider environment. Again, organic contaminants may be adsorbed on to the surfaces of clay minerals, after which they may be broken down to more harmless compounds by microbiological activity.

Apart from the importance of weathering to life, the process occupies a unique place in the geological cycle in that it is located at the interface between the atmosphere, the hydrosphere and the biosphere. Indeed, life itself is an important agent of mineral weathering as will be shown later. In addition, weathering can occur at any stage in the geological cycle, effectively short-circuiting the cycle as a whole. Thus, depending upon the timing of uplift to the Earth's surface, weathering may ensue directly after sediment deposition, diagenesis, metamorphism, intrusion of plutonic rocks or extrusion of volcanic rocks (Fig. 1). Evidently, the composition of sedimentary rocks will be strongly influenced by the nature of weathering in the source area of the sediment.

Clearly, therefore, mineral weathering is a process of prime importance to the earth sciences, as well as to agricultural and environmental sciences, from many different points of view. This has become much more widely realized in recent decades as shown by the tremendous upsurge in research activity and in the volume of scientific literature dealing with weathering. In particular, there has been a great deal of work upon the detailed mechanisms of primary mineral weathering, the products formed from such weathering and the rates at which the process occurs. In this paper, some (but by no means all) of the more significant recent work on the weathering of primary minerals, including olivines, pyroxenes, amphiboles, feldspars, micas and chlorites, will be reviewed, from the particular context of location of the mineral in the weathering profile. As will be shown in the following discussion, position in the weathering profile has a crucial influence in determining the nature of the prevailing weathering environment, and consequently on the mechanisms involved, the products formed and the rates at which the process occurs. For the most part this review will deal with weathering as it occurs in acidic to circum-neutral conditions. 




FIG. 1. Weathering in the geological cycle.

\section{THE WEATHERING PROFILE}

There are of course many different kinds of weathering profile. Often such profiles are truncated because of mass movement, erosion, etc., but the most complete form is represented by a residual soil developed upon a disaggregated, saprolitic parent rock which itself overlies coherent, partly weathered bedrock. Delvigne (1998) has described the various components of the residual weathering profile in detail (Fig. 2) and shown how they may differ in terms of their fabric, texture and overall mineralogy. At the base of the profile, the parent

$\begin{array}{ll} & \text { A Horizon } \\ \text { Soil } & \text { B Horizon } \\ & \text { C Horizon }\end{array}$

Completely disaggregated rock, but fabric and texture lost

Saprolite/alterite

Completely disaggregated rock, but fabric and texture maintained

Weathered rock Hard coherent partly weathered rock with fractures and fissures

FIG. 2. Units of a fully developed weathering profile. rock is perfectly coherent but is marked by weathering related to fractures and fissures along which the weathering agent (generally water) has progressed. This is then succeeded by a discontinuous pattern of blocks of weathered and unweathered rock, which gradually gives way to a situation where virtually the whole body of the rock is weathered and disaggregated. This part of the profile is termed "alterite" by Delvigne (1998) and is broadly equivalent to what is known as saprolite. It is usually found that in the lower part of the saprolite the original fabric and texture of the bedrock are perfectly preserved, despite the almost complete disaggregation of the constituent mineral grains one from another. The coherence of the rock may be completely lost but it has maintained its original volume, leading Delvigne to suggest the term "isoalterite" for this part of the profile. The isoalterite may be several metres thick but eventually gives way to a situation where the original fabric and structure of the parent rock can no longer be recognized. This results from the alteration, movement and redistribution of certain mineral components and is often accompanied by a colour change due to formation of $\mathrm{Fe}$ oxide minerals. Delvigne distinguishes this part of the weathering profile as "alloterite". At the top of the weathering profile and often grading down into the saprolite there is what soil scientists generally think of as the soil itself. This is usually characterized by a sequence of horizons designated as $\mathrm{A}, \mathrm{B}$ and $\mathrm{C}$. The A horizon occurs close to the surface and consists of a mixture of minerals and humified 
organic matter, although the eluviation of both materials down the profile may have occurred. The $B$ is a subsurface horizon characterized by the illuviation and accumulation of minerals and organic matter from higher up in the profile, whereas the basal $\mathrm{C}$ horizon consists of unconsolidated mineral material which does not show the characteristic properties of the A and B horizons,

Consideration of primary mineral weathering in the context of the complete weathering profile is important because quite different chemical and physical conditions obtain in the various parts of the profile. This aspect has been discussed in some detail in a perceptive review of the microscopic aspects of mineral weathering by Hochella \& Banfield (1996). For example, the surface area of mineral grains, whether measured geometrically or by BET methods (which take into account both surface roughness and internal surface area) are at a minimum in the weathered rock, at a maximum in the soil and at an intermediate level in the saprolite. Therefore, reactive mineral surface will similarly increase towards the surface, although it may be noted that grain size will not always correlate with reactive surface. Again, porosity and permeability will vary in different parts of the weathering profile, generally increasing upwards and being at a maximum in the soil. This means that hydraulic conductivity will increase in the same direction, although it should be borne in mind that structural features in the weathering profile may lead to channel flow. Nevertheless, the actual nature of the water may change within different parts of the weathering profile. In the soil, gravitational, drainage or freely flowing water will predominate, whereas in the weathered rock at the base of the profile there will be a greater proportion of stagnant or capillary water. This will mean that weathering minerals will be closer to equilibrium with external fluids at the base of the profile but furthest away from equilibrium in the soil layers. Moreover, vegetation growing in the soil will act as a sink for cations released by the weathering minerals and thus move the system even further away from equilibrium. The $\mathrm{pH}$ value of the waters in the weathering profile is also likely to vary markedly. This is likely to be lowest in the soil horizons and highest in the weathered rock where the basic cations from the weathering minerals will be more easily retained in the stagnant water. In addition, organic ligands resulting from the decomposition of organic matter will be a more important weathering factor in the soil horizons. Redox conditions too may vary in the different parts of the weathering profile, tending to be most oxidizing in the soil and least oxidizing in the weathered rock. Finally, it may be expected that a direct microbiological effect on mineral weathering through, for example, the excretion of organic acids, will be more important in the soil compared with the weathered rock or saprolite.

In addition to the variation in physical and chemical conditions within the weathering profile, it should be borne in mind that the overall nature of the soil, and to a large extent that of the saprolite and weathered rock, will depend upon the five classical factors identified by Jenny (1941), namely climate, topographic position (influencing drainage), parent material, time and biota.

An outline of the general mechanisms by which mineral weathering operates in the different parts of the weathering profile may now be given. In the weathering rock at the base of the profile, the capillary/stagnant water may be close to equilibrium with individual primary minerals and will tend to form weathering products that bear a close chemical and structural relationship to these minerals. Reactions may be slow and diffusioncontrolled, often affecting the internal surface area of the primary mineral. In the isoalterite part of the saprolite, the minerals are more affected by freely flowing drainage waters whose composition will tend to reflect the interaction between bulk water and bulk parent material. Therefore, equilibrium between these waters and individual primary minerals will not be attained and a close structural and chemical relationship between a specific primary mineral and a weathering product may not expected to occur. In the alloterite, the destruction of a coherent rock fabric means that such a relationship is even less likely. Within the saprolite and in the lowest parts of the soil profile, mechanisms for the aqueous dissolution of the primary minerals assume greater significance and the results of laboratory dissolution experiments are of greatest relevance to natural weathering processes. Within the soil profile itself, the role of organic ligands derived from decomposing organic matter, in addition to the activities of soil microbes and plant roots, will be of relatively greater importance in primary mineral weathering, in comparison with the mainly inorganic processes dominating in the lower parts of the weathering profile. 
ROLE OF THE PRIMARY MINERAL IN INITIATING WEATHERING REACTIONS

In addition to the environmental factors discussed above, the nature and rate of the weathering process clearly depends upon the nature of the primary minerals themselves. This was recognized by Goldich (1938) who showed that the overall susceptibility to weathering of the common primary minerals was related to the discontinuous and continuous reaction series identified in magmatic crystallization. Thus, olivine and anorthite, the first formed minerals in the discontinuous and continuous reaction series, respectively, are the most susceptible to weathering. In both series, minerals that crystallize at successively lower temperatures are more stable to weathering, with quartz, muscovite and K-feldspar being particularly resistant. This variation relates to the differential between conditions at magmatic crystallization and at the Earth's surface during weathering, as well as to overall mineral structure and chemistry. However, in recent decades it has become apparent that susceptibility to weathering also depends very much upon the more detailed features of mineral structure and chemistry. As will be shown later, dislocation and defect structures are particularly important in determining the sites where weathering is initiated, as are the inhomogeneities in chemical composition induced by micro-textural features. Furthermore, such details have a direct bearing upon questions related to the fundamental mechanisms by which weathering proceeds.

\section{WEATHERING OF OLIVINE}

\section{Transformations in fresh and weathered rock}

Delvigne et al. (1979) reviewed the way in which olivine weathers in a variety of situations mainly from a microscopic or micromorphological point of view. They pointed out that usually olivine is destroyed or replaced during the early stages of weathering and consequently is normally not found to any great extent in soils, except under unusual circumstances. They also emphasized that in fresh rocks olivine is often already altered by magmatic and metamorphic transformations to orthopyroxenes, serpentines or talc and by deuteric or hydrothermal processes to mixtures of hydrous phyllosilicates and $\mathrm{Fe}$ oxide minerals. In the latter case, the most common product is iddingsite, which may be optically homogeneous and crystallographically orientated with respect to the parent olivine (Brown and Stephen, 1959). The transformation from olivine to iddingsite was studied in detail by Eggleton (1984) using transmission electron microscopy of ion-beam thinned specimens. A two-stage process was proposed. In the first stage, the olivine breaks down into thin lamellae consisting of a metastable hexagonal phase and elongated parallel to the olivine $c$ axis. This transformation opens up solution channels which become infilled with lathlike crystals of saponite, whose (001) parallels the olivine (100), and crystallites of goethite. This early transformation is thus considered to be of an epitaxial or topotactic nature. In a second stage, water migrates more freely through the solution channels permitting further growth of the smectite and goethite nuclei formed during early alteration and largely, but not entirely, maintaining the early orientation relationship with the parent olivine. In this instance, alteration was undoubtedly due to deuteric/hydrothermal activity, although weathering was considered to result in similar mineral assemblages.

This point was amplified in a later study on the weathering of olivine in basalt to iddingsite by Smith et al. (1987). Three different basalts were examined. In each, the process of iddingsitization appears to have commenced before weathering, but progresses to completion as a result of later weathering. Iddingsite formation again involves etching along lamellar zones parallel to (001) and formation of smectite and oriented goethite within these zones. An important finding, however, is that some elements such as $\mathrm{Al}$ and $\mathrm{Na}$, have been introduced from outside the weathering olivine crystal, showing that the process is not truly isochemical. In fact, in the later stages of decomposition, dioctahedral smectite and halloysite are associated with the weathered olivine.

The initial stages of the alteration of olivine were explored in further detail by Banfield et al. (1990). It was found that in altered basaltic andesites the olivine consisted of fine intergrowths of forsteriterich olivine and laihunite, an oxidized fayalitic phase where structural ferric iron is balanced by structural vacancies resulting in a distorted olivine structure. Where the intergrowths are widely spaced, the laihunite may act as a barrier to weathering, resulting in the preferential dissolution 
and etching out of the forsterite to yield textures very similar to those reported by Eggleton (1984) and Smith et al. (1987). The etched out channels are first filled with semi-oriented aggregates of saponitic clay and subsequently with aggregates of oriented hematite crystals. Banfield et al. (1990) concede that there is no firm evidence to decide if these products result from deuteric alteration or weathering, although in a further transmission electron microscope (TEM) study (Banfield et al., 1991), they definitely attributed these changes to weathering. The occasional presence of appreciable $\mathrm{Al}$ in the smectites associated with weathering olivine indicates that micro-environmental control is by no means complete and that ions diffusing into the decomposing olivine grains derive from extraneous sources. This was clear from an earlier study of lateritic weathering of olivine-bearing rocks by Nahon et al. (1982). It was shown that early-formed smectites were trioctahedral but that as weathering progressed they were replaced by dioctahedral (beidellitic-nontronitic) varieties. Further weathering results in the replacement of these smectites by amorphous and well crystallized oxyhydroxides.

In the context of the weathering profile as a whole, there is no doubt that the smectitic minerals that form from olivine in weathered rock are quite ephemeral. Once these products are removed from the relatively closed near-equilibrium situation that exists in the weathered rock and placed within the more open, far-from-equilibrium situation that prevails throughout the saprolite and the soil, then they quickly disappear. Quantitatively, therefore, in the context of the weathering profile as a whole these early weathering products may be relatively unimportant.

\section{Weathering in basal saprolite}

The formation of early weathering products like those found in weathered rock may be completely bypassed in the situation where the fluid to mineral ratio increases dramatically, as might be anticipated, for example, in the disaggregated and incoherent saprolite higher up in the weathering profile. The saprolite at the base of the profile (termed 'gruss' in German or 'arène' in French) is often characterized by physical incoherence but little or no chemical weathering. Here, disaggregated grains of olivine may be subjected to dissolution effects similar to those described in laboratory experiments. While such experiments do not necessarily simulate natural weathering (Casey et al., 1993), they do show how the rate of dissolution of olivine depends on the detailed nature of the mineral itself, particularly its composition, crystallography, dislocation density and micro-textural features, as well as on the chemistry of the external solution, including $\mathrm{pH}$, ion activities and redox conditions.

The effect of overall structure on dissolution kinetics under acid conditions of gem quality forsteritic olivine has recently been elegantly demonstrated by Awad et al. (2000). They showed that there was a much higher dissolution rate along the $b$ axis (Table 1), attributing this to preferential protonation of the $\mathrm{O}$ atoms that surround the cations in the $M 1$ site in the form of a distorted octahedron. Dissolution occurred through the formation of etch pits parallel to (010), $(h k 0)$ and $(\bar{h} k 0)$.

The mechanism involved in the aqueous dissolution of forsteritic olivine at Earth surface-temperatures in an open-system, mixed-flow reactor over a wide range of $\mathrm{pH}$ values and solution compositions has recently been reviewed and investigated by Pokrovsky and Schott (2000a,b). They concluded that at acid and slightly alkaline $\mathrm{pH}$ values, a silicarich protonated precursor complex several unit cells thick forms at the surface of the mineral through exchange of $\mathrm{H}^{+}$with $\mathrm{Mg}^{2+}$ according to the reaction:

$$
\mathrm{Mg}_{2} \mathrm{SiO}_{4} \text { (surf) }+4 \mathrm{H}_{(\mathrm{aq})}^{+}=>\mathrm{H}-\mathrm{SiO}_{4(\text { surf })}+2 \mathrm{Mg}_{(\mathrm{aq})}^{2+}
$$

This is followed by polymerization of partially protonated $\mathrm{SiO}_{4}$ tetrahedra, penetration of $\mathrm{H}^{+}$into the leached layer and adsorption of $\mathrm{H}^{+}$on silica dimers. Dissolution rate is non-stoichiometric in the first $\sim 10 \mathrm{~h}$ of the experiment but then becomes stoichiometric thereafter. The decomposition of the surface complex is the rate-limiting step controlling forsterite dissolution under acid conditions. The forsterite grains are characteristically etched,

TABLE 1. Dissolution rates $\left(\mathrm{mm} \mathrm{h}^{-1}\right)$ of gem-quality olivine at $23^{\circ} \mathrm{C}$ and $50^{\circ} \mathrm{C}$ at $\mathrm{pH} 1$ along the crystallographic axes (data from Awad et al., 2000).

\begin{tabular}{lccc}
\hline Temperature & $a$ axis & $b$ axis & $c$ axis \\
\hline $23^{\circ} \mathrm{C}$ & $2.38 \times 10^{-5}$ & $1.46 \times 10^{-4}$ & $7.16 \times 10^{-6}$ \\
$50^{\circ} \mathrm{C}$ & $3.01 \times 10^{-5}$ & $1.53 \times 10^{-3}$ & $1.72 \times 10^{-4}$ \\
& & & \\
\hline
\end{tabular}



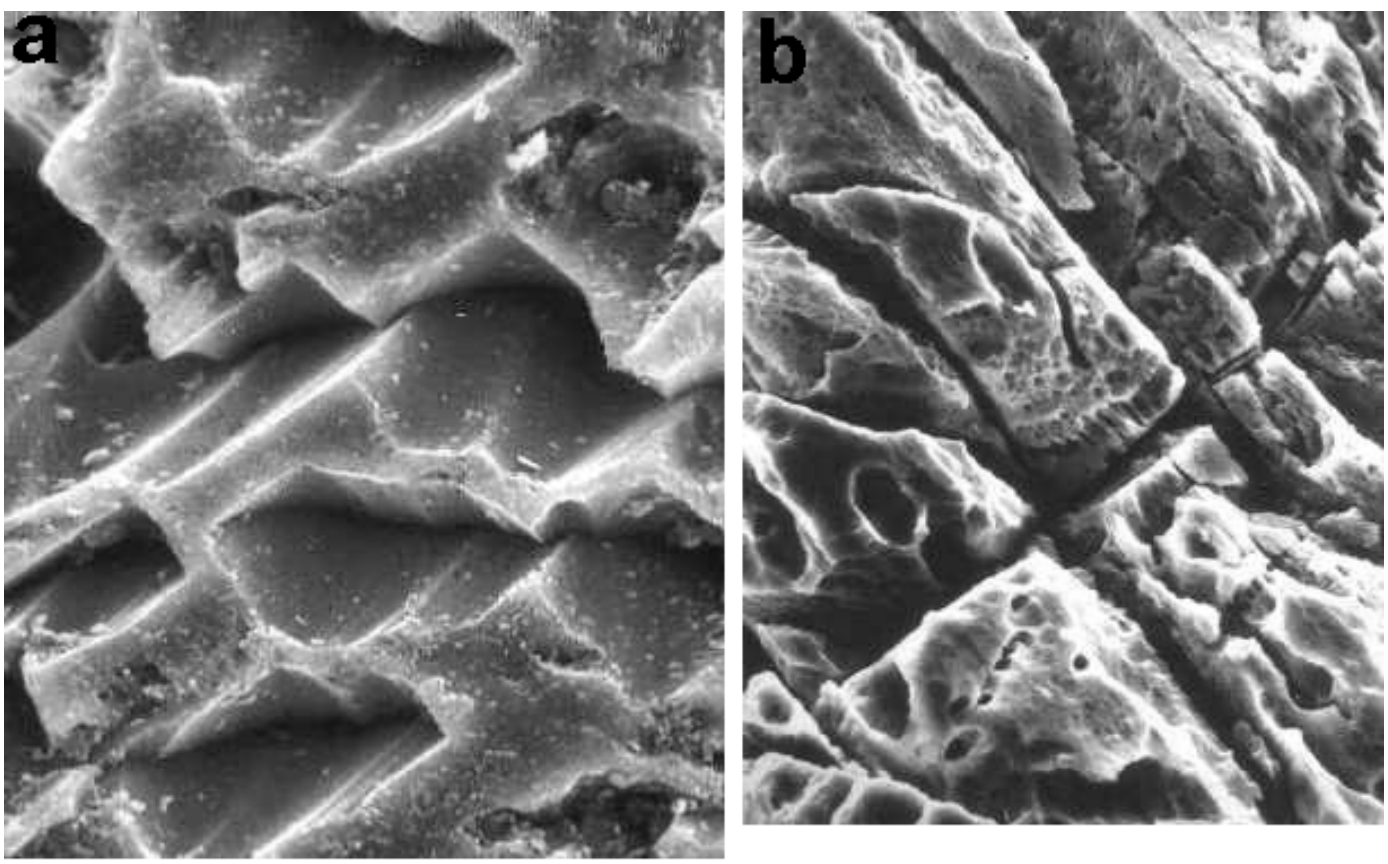

FIG. 3. (a) SEM (100 $\mu \mathrm{m}$ wide) of surface of etched olivine from a montane soil developed on allivalite on the island of Rhum; (b) SEM (150 $\mu \mathrm{m}$ wide) of etched olivine from gabbro boulder beneath a lichen at Pitcaple, Aberdeenshire (Wilson \& Jones, 1983).

showing that dissolution occurs preferentially at specific sites that may be crystallographically controlled (Awad et al., 2000) or that may mark the emergence of dislocations or defects, as suggested by Grandstaff (1978). The relationship between etch markings and structural dislocations in olivine has been well illustrated by Kirby \& Wegner (1978). Weathered olivines are found to be heavily etched (Fig. 3), suggesting that dissolution experiments like those described above are relevant to some natural conditions, despite the cautionary comments of Casey et al. (1993). Comparative dissolution experiments such as those of Franke and Teschner-Steinhardt (1994) clearly show that the weathering of olivine proceeds at a substantially faster rate than the other ferromagnesian minerals in the discontinuous reaction series (Table 2)

\section{Weathering in soils and upper saprolites}

Olivine is rarely found in soils and the upper parts of saprolites because of its extreme susceptibility to weathering, but Delvigne et al. (1979) identified three situations where it may be found.
These are (1) in sandy and rocky material in the vicinity of actively eroding ultrabasic or basic outcrops, (e.g. Wilson, 1969); (2) in soils derived from recent volcanic ash deposits; and (3) in soils where olivine is protected by a cortex of iddingsite or a reaction rim of pyroxene or garnet. Usually, olivine weathers quickly in the soil to mixtures of various hydrous clay minerals and Fe oxides/ oxyhydroxides. Thus Prudêncao et al. (2002) found, in a profile on weathered basalt, that olivine decomposed to a mixture of dioctahedral aluminous smectite and halloysite, illustrating the

TABLE 2. Rates of mineral dissolution $\left(\mathrm{mg} \mathrm{m}^{2}\right.$ day $\left.^{-1}\right)$ obtained in the experiments of Franke \& TeschnerSteinhardt (1994).

\begin{tabular}{lll}
\hline Mineral & $\mathrm{pH} 5.5$ & $\mathrm{pH} 4.0$ \\
\hline Olivine & $200-400$ & $6000-8000$ \\
Pyroxene & $14-25$ & $20-200$ \\
Hornblende & $26-30$ & $100-200$ \\
Biotite & $1.5-1.8$ & $42-53$ \\
\hline
\end{tabular}


requirement for inputs of $\mathrm{Al}$ from external sources. If olivine does survive into the soil then it is likely to be subjected to attack by microbial activity and by organic acids in addition to inorganic chemical weathering. Welch and Banfield (2002) showed that the interaction between the Fe-oxidizing chemoautotroph Acidothiobacillus ferrooxidans and fayalite resulted in distinctive dissolution textures, typically consisting of finely etched out channels on the (001) face and similar to features previously observed in abiotically weathered samples. The inter-channel strips contained a greater abundance of laihunite, which appeared to be less reactive to weathering, thus leading to preferential attack on the fayalitic olivine. This microbial alteration brought about an order of magnitude increase in surface area of the fayalite grains but at the same time would probably make them so susceptible to disintegration that they would be unlikely to survive in a soil environment. The experiments of Varadachari et al. (1994) show that olivine is completely decomposed after shaking with $0.5 \mathrm{~m}$ oxalic acid after 30 days and Drever (1994), while minimizing the overall effect of chelation by organic ligands on mineral weathering rates, concedes that in the case of olivine there could be a significant effect.

\section{WEATHERING OF PYROXENES AND AMPHIBOLES}

\section{Transformations in weathered rock}

In weathered rock, both pyroxene and amphibole have been found to weather to hydrous layer silicates in a similar way to that described for olivine, namely via a mechanism involving a high degree of structural inheritance by the secondary phase from the primary mineral. Thus, Eggleton (1975) showed that, in a clay pocket in weathered skarn, the pyroxene hedenbergite converted to nontronite maintaining complete optical continuity and constant volume throughout. X-ray and electron diffraction showed that the two phases were crystallographically coherent and a topotactic mechanism was proposed involving disconnection of pyroxene chains following changes resulting from the loss of $\mathrm{Ca}^{2+}, \mathrm{Mg}^{2+}$ and $\mathrm{Si}^{4+}$, oxidation of $\mathrm{Fe}^{2+}$ and hydration. Reconnection of tetrahedral silicic and octahedral ferric chains then occurred through movement in the $\{010\}$ pyroxene chain to form the nontronitic 'talc'-like units. Eggleton and
Boland (1982) conducted further studies on the weathering of enstatite to talc in a mafic rock. This transformation was considered to be a definite topotactic reaction with strict crystallographic continuity where the (001), (100) and (010) of the pyroxene become the (100), (001) and (010), respectively of talc. Further weathering results in the orientation relationship being lost with progressive replacement of the talc by smectite and sometimes smectite-chlorite. Basham (1974) had previously described the weathering of augite and hypersthene to pseudomorphs of vermiculite in weathered gabbro, where the $c$ axis of the vermiculite was oriented at right angles to the $c$ axis of the pyroxene. It was concluded that the host pyroxene exerted close structural control over the development of the hydrous mineral. In a study of what was taken to be natural weathering of pyroxenoid from a hydrothermal vein, Banfield et al. (1995) concluded that alteration in the form of etch pits commenced at grain boundaries and planar defects between intergrown rhodonite and pyroxmangite. These etch pits are filled with a $\mathrm{Zn}$-rich manganous smectite (the $\mathrm{Zn}$ being derived from associated weathered sphalerite) which is first welloriented but which later becomes randomly oriented as the etch pits enlarge. Similarly, in a study of amphibole weathering Banfield \& Barker (1994) found that reactions were focused in finely exsolved gedrite and anthophyllite lamellae which converted isovolumetrically and topotactically to smectite. The reaction was inferred to be a diffusioncontrolled, solid-state process, involving only partial depolymerization of the amphibole structure and with no intermediate amorphous-type material.

In contrast to these findings, Singh \& Gilkes (1993) showed that the weathering of the pyroxene spodumene in coherent weathered rock at the base of a lateritized pegmatite proceeded by replacement by randomly oriented smectite in etch pits and cleavage cracks via formation of some intermediate non-crystalline material. It was concluded, therefore, that weathering had proceeded by complete breakdown of the spodumene structure involving a solution process and precipitation of an amorphous phase. These findings are in accord with those of Nahon \& Colin (1982) who identified amorphous intermediary products during the weathering of orthopyroxene (enstatite and bronzite) at the base of a lateritic weathering profile in the Ivory Coast. A possible reason for these different findings is that the materials studied by Eggleton (1975), Eggleton 
\& Boland (1982), Banfield \& Barker (1994) and Banfield et al. (1995) had previously been subjected to hydrothermal or deuteric alteration involving formation of hydrous phyllosilicates from the primary mineral, which was thus predisposed to continued transformation along the same pathway in the confined space of weathered rock at the base of the profile.

\section{Weathering in saprolite}

In the saprolite, disaggregated pyroxene and amphibole grains may be subjected to aqueous dissolution processes similar to those studied in through-flow reactors. The processes and mechanisms involved have been reviewed extensively by Brantley \& Chen (1995). Early experiments, such as those conducted by Luce et al. (1972) on the dissolution of enstatite, showed parabolic dissolution kinetics, which were interpreted as being consistent with diffusion of ions through a cationdepleted, silica-enriched shell surrounding the mineral grains. Parabolic dissolution kinetics were also found for bronzite (Grandstaff, 1977) and for hypersthene (Siever \& Woodford, 1979). However,
Schott et al. (1981) in aqueous dissolution experiments on enstatite, diopside and tremolite suggested that the parabolic dissolution kinetics were an experimental artefact induced by the creation of ultra-fine particles by grinding. Further, they proposed that dissolution is controlled by reactions at the mineral surface and does not proceed by diffusion through a residual layer. Calcium and $\mathrm{Mg}$ are initially released preferentially for structural reasons, after which dissolution becomes congruent and linear. X-ray photoelectron spectroscopy (XPS) suggested a cation-depleted layer at the mineral surface only 5 to $20 \AA$ thick, too thin to be rate limiting with respect to diffusion. Similar conclusions were arrived at with respect to the aqueous dissolution of the Fe-rich bronzite, both in the presence and absence of dissolved oxygen (Schott \& Berner, 1983). Other evidence for a surface-controlled mechanism for dissolution of pyroxenes and amphiboles is the universal occurrence of etch pits in weathered grains (Fig. 4), which are thought to develop at points where structural dislocations occur at the mineral surface (Berner et al., 1980, Berner \& Schott, 1982). However, this interpretation of the dissolution
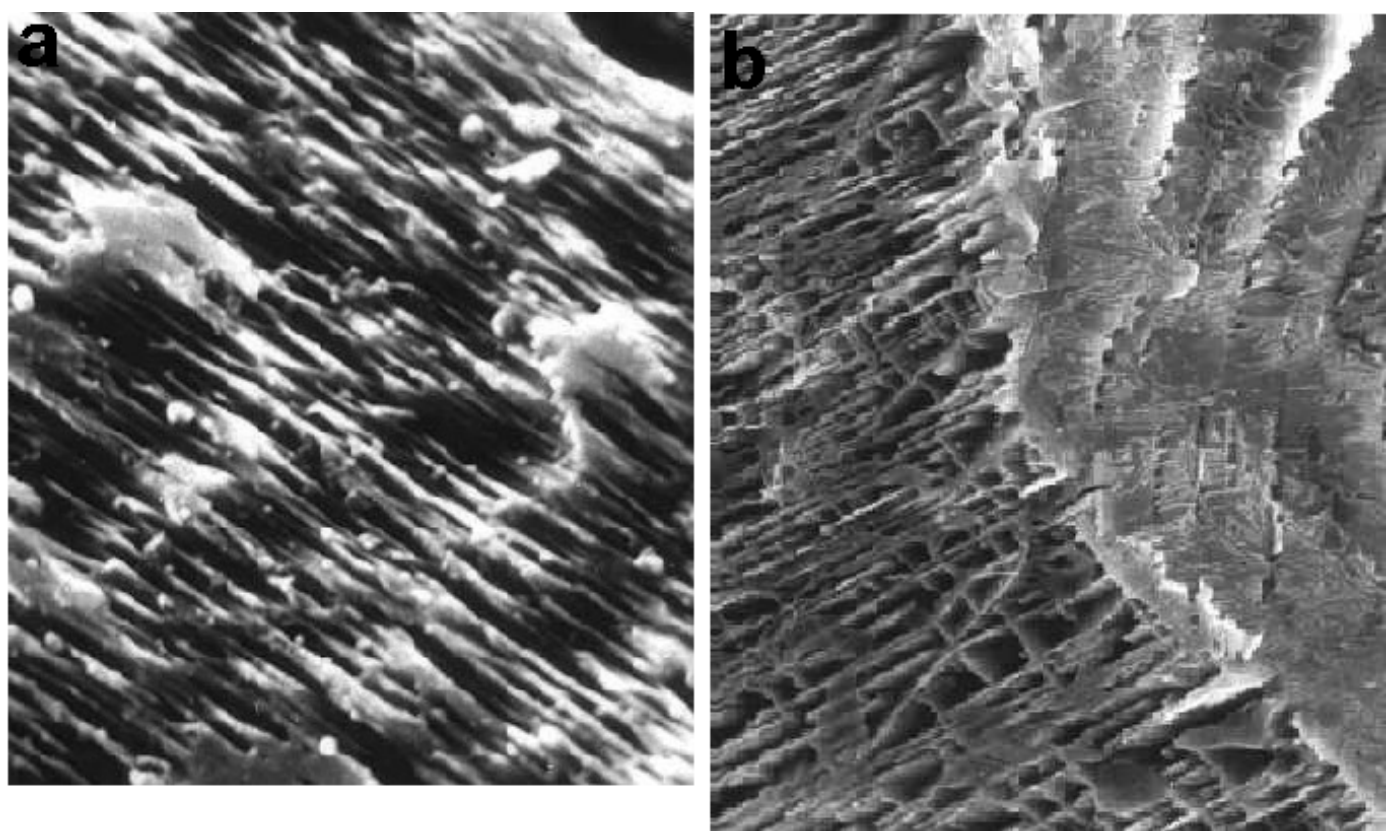

FIG. 4. (a) SEM (200 $\mu \mathrm{m}$ wide) of deeply etched cleavage planes of clinopyroxene in soil derived from volcanic material, Italy (Violante \& Wilson, 1983). (b) SEM (75 $\mu \mathrm{m}$ wide) of etched-out lamellar intergrowths of clinopyroxene separated from gabbro after incubation in a culture with Aspergillus niger (Wilson \& Jones, 1983). 
process is still open to question following further research on altered grains using advanced techniques. Thus, Petit et al. (1987) showed by hydrogendepth profiling using a resonant nuclear reaction (RNR) technique, that diopside dissolution proceeds via surficial hydration through a thickness of about $1000 \AA$, coupled with a depletion of all elements. It was proposed that the leached layer formed by the migration of molecular water through the structure along defects and that reaction with the silicate network created a more open porous structure further enhancing water migration. These observations were not thought to be incompatible with the earlier conclusions of Schott et al. (1981) that the dissolution of diopside did not occur through a leached surface layer. However, Mogk \& Locke (1988) used Auger Electron Spectroscopy (AES) to study naturally weathered hornblende and concluded that there was systematic cation depletion to depths of $\sim 1200 \AA$, indicating that weathering cannot be accounted for by surface reactions alone, but must also involve depletion of cations through volume diffusion. They concluded that their results support a non-steady-state diffusion model, as proposed by Luce et al. (1972), but that the kinetics of mineral dissolution in general, whether by laboratory experiments or natural processes, is controlled by a balance of surface reactions and volume diffusion. The results of Zhang et al. (1993) on the experimental weathering of hornblende of different size fractions also indicated surface enrichment of $\mathrm{Si}$ compared with $\mathrm{Ca}, \mathrm{Al}, \mathrm{Mg}$ and Fe. Following the conclusions of Blum et al. (1990) for the dissolution of quartz, they discounted a direct relationship between dissolution rate and dislocation density, although surface etching of the minerals did occur, clearly showing selective dissolution at high energy sites.

The rates of dissolution of pyroxenes and amphiboles under ambient conditions, together with all the many factors that may affect these rates, have been reviewed in detail by Brantley \& Chen (1995). Table 3 shows selected dissolution rates with respect to silica of some of the most common pyroxenes and amphiboles in the $\mathrm{pH}$ range 4.0 to 6.0 at ambient temperatures. It can be seen that dissolution rates do not always necessarily increase with decreasing $\mathrm{pH}$, (in the case of augite, anthophyllite and hornblende), that enstatite (though not bronzite) and diopside are least stable to dissolution weathering under acid conditions, and that both augite and hornblende are much more stable to aqueous dissolution when compared with olivine.

\section{Weathering in the upper saprolite and soil}

Turning to the nature of pyroxene/hornblende decomposition in the upper parts of the weathering profile, Nahon \& Colin (1982) showed that orthopyroxene transformed directly to clay mineral products under more intense weathering conditions. Specifically, they identified smectites intermediate in composition between dioctahedral (beidellitenontronite) and trioctahedral (saponite) types, as well as a talc-like mineral with interstratified swelling layers. These minerals pseudomorphed the original orthopyroxene but were not structurally related to it. Further weathering resulted in the decomposition of the clay minerals and the formation of well crystallized goethite via a ferrihydrite stage. Delvigne (1998) illustrates how pyroxene that is completely weathered to goethite can be infilled by gibbsite of allocthonous origin. Proust (1982) drew a clear distinction between the weathering products formed at the base of the profile, where rock structure is preserved, and those forming higher up in the profile where structure is

TABLE 3. Dissolution rates for some common pyroxenes and amphiboles with respect to silica $\left(\right.$ moles $\mathrm{cm}^{2} \mathrm{~s}^{-1}$ ) at $25^{\circ} \mathrm{C}$ between $\mathrm{pH}$ 4.0 to $\sim 6.0$ (selected from data compiled by Brantley \& Chen (1995); dissolution rates for olivine from Pokrovsky \& Schott (2000b).

\begin{tabular}{lcc}
\hline Mineral & $\mathrm{pH}$ & $-\log R_{\mathrm{Si}}$ \\
\hline Enstatite & 4.8 & -13.8 \\
& 6.0 & -16.4 \\
Bronzite & 4.0 & -15.8 \\
& 6.0 & -16.0 \\
Diopside & 4.0 & -13.3 \\
& 6.0 & -14.8 \\
Augite & 4.1 & -16.1 \\
& 6.0 & -14.9 \\
Anthophyllite & 4.0 & -15.7 \\
& 6.0 & -14.8 \\
Tremolite & 6.0 & -14.8 \\
Hornblende & 4.0 & -15.9 \\
& 6.0 & -15.6 \\
Glaucophane & 6.2 & -14.6 \\
Olivine & 4.2 & -12.7 \\
& 6.1 & -13.9 \\
\hline
\end{tabular}


lost. It was found that saponite forms at the base of the profile but that this is replaced towards the surface by vermiculite which eventually gives way to a dioctahedral vermiculite-beidellite assemblage. Earlier, Wilson \& Farmer (1970) had found that discrete Fe-rich lamellae of another amphibole within hornblende weathered selectively to an interstratified swelling chlorite-saponite, which was not oriented relative to the parent mineral other than showing a tendency to alignment along cleavage planes. This clay mineral decomposed completely in the upper parts of the profile.

The consequences of more intense weathering of hornblende were revealed by Anand \& Gilkes (1984). It was found that the hornblende in a weathered meta-dolerite simply disappeared as there was insufficient Al to form kaolin minerals, as was the case with plagioclase feldspar. Similarly, in a weathered plagioclase-hornblende gneiss, Velbel (1989) found the amphibole to have dissolved stoichiometrically, followed by the precipitation of goethite, gibbsite and kaolinite within and around the primary mineral. Complete removal of the latter left a porous, ferruginous boxwork of weathering products, with optically oriented pendants projecting into the void spaces. It was concluded that these textures had been formed both by neoformation and transformation mechanisms. In soils both pyroxenes and amphiboles are frequently found to be heavily etched, as described in detail by Berner et al. (1980) and Berner \& Schott (1982). Even in Arctic soils, such etching is prominent, increasing with the age of the soil and enabling weathering rates to be calculated (Locke, 1986).

\section{WEATHERING OF FELDSPARS}

\section{Transformations in weathered rock}

The earliest stages of feldspar decomposition in the weathered rock stage were investigated by Eggleton \& Buseck (1980) in their high-resolution TEM (HRTEM) study of partly altered K-feldspar megacrysts in granodiorite. Weathering of the feldspar was considered to take place at structural defects, particularly at the boundary of twinned and untwinned domains, firstly yielding amorphous materials. These materials later crystallized to what was interpreted as interstratified illite-montmorillonite, although no XRD evidence was presented. A further TEM study was made of the weathering of K-feldspar and plagioclase feldspar in altered granodiorite by Banfield \& Eggleton (1990). Poorly crystallized (proto-crystalline) material was again identified as an initial weathering product forming within etch pits in both feldspars. In plagioclase this material was later replaced by randomly oriented smectite containing $\mathrm{Fe}, \mathrm{Ca}$ and $\mathrm{K}$, and then later by halloysite. Similar weathering products were associated with the K-feldspar. Eswaran \& Bin (1978) had earlier observed in slightly weathered rock at the base of a deep weathering profile in Malaysia that amorphous material accumulated in plagioclase trans-grain voids, later transforming to halloysite. Para-crystalline clay precursors were also observed in the weathering of $\mathrm{K}$-feldspar in an alkaline igneous complex in Brazil (Tazaki \& Fyfe, 1987). These precursors showed primitive circular morphology, yielded diffuse electron diffraction patterns and probably transformed mainly into spheroidal halloysite. On the other hand, Anand et al. (1985) could find no evidence for the occurrence of noncrystalline material as an intermediate stage in their study of feldspar weathering in Western Australia. In this instance, the feldspar was observed to weather directly to halloysite and gibbsite, although this could represent a later stage of weathering as the material studied is described as saprolite rather than weathered rock.

\section{Weathering in saprolite and soils}

Dissolution mechanism. As outlined above, the reactions in the saprolite may be considered as comparable in some ways to the alteration process that occurs in an experimental through-flow reactor, about which there is still some controversy. The main features of this debate concern the mechanism of feldspar dissolution, with particular points of interest as far as this paper is concerned, being the role of dislocations, defects and micro-textural features in the dissolution process of the exposed mineral surface. These and other areas of feldspar dissolution kinetics were comprehensively reviewed by Blum \& Stillings (1995), but there have been interesting developments since then. Early studies of the experimental dissolution of feldspar seemed to show that the process was incongruent and was consistent with the hypothesis of a leached layer (Wollast, 1967). This hypothesis requires that a cation-depleted coating, consisting of $\mathrm{Si}$ and $\mathrm{Al}$, forms around the weathering feldspar grain and thence controls the rate at which cations are 
released from the feldspar structure. These cations must first exchange with $\mathrm{H}^{+}$ions and then diffuse by a solid state mechanism from the interior of the feldspar, through the leached layer into the external solution. This leached layer maintains a constant thickness, because it too is gradually dissolving at a constant rate and tightly adheres to the feldspar grain. This hypothesis was widely accepted until the work of Berner and his colleagues threw doubt upon the existence of a leached layer in both experimentally altered and naturally weathered feldspars. Firstly, Petrovich et al. (1976) used $\mathrm{X}$-ray photoelectron spectroscopy (XPS) to show that on experimentally altered sanidine grains, if a leached layer did exist it was no more than $\sim 17 \AA$ thick, which is far too thin to control the rate of diffusion of cations into the external solution. Holdren \& Berner (1979) presented further XPS and SEM evidence to show that there was no leached layer in an experimentally altered albite, suggesting instead that feldspar dissolution was a surface-controlled reaction. They accounted for the parabolic dissolution kinetics of feldspar dissolution by proposing that the process occurred in two stages, the first being due to the non-linear dissolution of ultra-fine particles produced by grinding, and the second to linear dissolution at sites of excess surface energy due to the emergence of dislocations or defects. These sites are revealed by distinctive patterns of etch pitting both in naturally and experimentally weathered feldspars and were considered to be fundamentally inconsistent with the residual leached layer hypothesis (Wilson, 1975, Berner \& Holdren, 1979). The latter authors also showed that XPS data on naturally weathered albite, oligoclase and microcline did not support the existence of a residual coating, although the conclusions of Chou \& Wollast (1984) following their study of the laboratory weathering of albite appeared to challenge this interpretation. However, in published correspondence between the two groups of authors (Berner et al., 1985; Chou \& Wollast, 1985) it was agreed that the XPS data could be reconciled with the solution chemical results if dissolution occurred preferentially at dislocations which intersected only a small part of the mineral surface.

Later studies, particularly focusing on plagioclase feldspars, have added further detail to the mechanism involved in their alteration and have also addressed the question of the extent to which laboratory experiments can simulate natural weath- ering processes. These studies have made use of depth profiling techniques to establish definitively the nature of any residual surface layer. Using backscattering spectrometry, Casey et al. (1989) showed that labradorite in acid solutions ( $\mathrm{pH} 1$ to 3 ) was infiltrated by $\mathrm{H}^{+}$ions to a depth of several hundred Angstroms, resulting in depletion of $\mathrm{Na}^{+}, \mathrm{Ca}^{2+}$ and $\mathrm{Al}^{3+}$ and in the production of an amorphous Si-rich surface. At higher $\mathrm{pH}$ values though, there is only limited penetration of $\mathrm{H}^{+}$ions and dissolution occurs at the immediate mineral surface. Similar conclusions were reached by Muir et al. (1989) after reacting labradorite in solutions of $\mathrm{pH} 3.5$ and 5.7, using secondary ion mass spectrometry (SIMS) and XPS. Furthermore, extensive etching was observed on some of the mineral surfaces, showing that dissolution was occurring at selected sites of weakness. A later SIMS and XPS investigation showed that the thickness of the siliceous leached layer depended directly upon the composition of the plagioclase feldspar, as well as the $\mathrm{pH}$ of the altering solution (Muir et al., 1990). The thickness of the layer increased in the order albite $<$ oligoclase $<$ labradorite $<$ bytownite and underlined the importance of the hydrolysis of $\mathrm{Si}-\mathrm{O}-\mathrm{Al}$ bonds in the mineral structure. Casey et al. (1991b) quantified the influence of plagioclase composition on dissolution rates at $\mathrm{pH} 3$ and showed that these rates varied non-linearly for the Ca-rich feldspars and were more variable than the Na-rich feldspars. Dissolution rates $(-\log R)$ of various plagioclases as a function of mole \% anorthite in $\mathrm{pH} 3.0$ solutions range from $\sim 10^{-15}$ for albite, to $10^{-14}$ for bytownite, to $10^{-13}$ for anorthite.

Nesbitt et al. (1991) addressed the question of the influence of dissolved cations on the mechanism of dissolution of labradorite in acidic solutions. Using SIMS, they found that no residual layer formed after leaching with distilled water, that $\mathrm{HCl}$ leaching yielded a $1500 \AA$ thick silica-rich layer and that the addition of $\mathrm{Na}, \mathrm{K}, \mathrm{Ca}$ and $\mathrm{Al}$ to the acid could reduce this thickness to $<75 \AA$. They concluded that incongruent dissolution occurs in $\mathrm{HCl}$ solution but that congruent dissolution occurs in most electrolyte solutions where dissolved cations are more abundant than protons. For most natural soil solutions this would be the expected situation and consequently extensive leached layers would be unlikely to occur on naturally weathered feldspar grains, consistent with the observations of Berner \& Holdren (1979). However, Stillings and 
Brantley (1995) and Brantley \& Stillings (1996) found that most of the feldspars that they examined, except oligoclase and labradorite, dissolved stoichiometrically in the laboratory, even without salts. Recent evidence from Teng et al. (2001) using atomic force microscopy (AFM) and synchrotron $\mathrm{X}$-ray reflectivity indicates that the (001) cleavage surfaces of orthoclase feldspar dissolves stoichiometrically under acid conditions ( $\mathrm{pH} 1)$ except for a non-stoichiometric layer of a single unit-cell thickness.

The nature of naturally weathered feldspar surfaces is still a subject of debate. Nesbitt \& Muir (1988) examined by SIMS the surface of oligoclase from weathered stones taken from a 10,000 year old till, and concluded that there was an enrichment of $\mathrm{Al}$ and a depletion of Si. As this contrasts with what is usually found in laboratory experiments, it was suggested that the results from such experiments may not be applicable to natural environments. But a more recent SIMS and AFM study of the surfaces of albite after burial in soil for various periods of time, showed that they were depleted in $\mathrm{Al}$ (and $\mathrm{Na}$ ), suggesting dissolution mechanisms similar to those observed in the laboratory (Nugent et al., 1998). The elevated $\mathrm{Al} / \mathrm{Si}$ ratios observed by Nesbitt \& Muir (1988) were attributed to a thin patchy coating of an alumino-silicate, undetectable by SEM but visible under the AFM.

\section{Influence of dislocations and microtexture on feldspar dissolution}

Many of the studies referred to above stress the influence of dislocations and defects, as well as compositional heterogeneities on the mechanism of feldspar dissolution, as well as the role of these features in increasing specific surface area. Wilson (1975) drew attention to the deeply etched nature of feldspar grains in some Scottish soils and, by analogy with correspondence between etch pits and dislocations in metals, surmized that there was a similar relationship in weathering feldspars. Berner \& Holdren (1977) independently arrived at a similar conclusion and provided compelling evidence to indicate that such etching essentially controlled the natural feldspar dissolution process (Berner \& Holdren, 1979). However, investigations such as those by Casey et al. (1991a) for rutile, Holdren et al. (1988) for calcic plagioclase feldspar, Schott et al. (1989) for calcite and Blum et al. (1990) for quartz, all arrive at the same conclusion, namely that for the minerals studied there is a very poor, or even no, correlation between dislocation density and dissolution rate in experimental systems. Thus, Blum et al. (1990) found virtually indistinguishable dissolution rates of synthetic quartz with a dislocation density of $<10^{5} \mathrm{~cm}^{-2}$ and the same plastically deformed quartz with a dislocation density of $\sim 5 \times 10^{10} \mathrm{~cm}^{-2}$ and dramatically increased etch pitting in distilled water at $80^{\circ} \mathrm{C}$ and in $0.2 \mathrm{M} \mathrm{HF}$ at $22^{\circ} \mathrm{C}$. It was concluded that etch-pit dissolution makes a minor contribution to overall dissolution rate of minerals, particularly in under-saturated systems such as soils. Despite such experimental evidence, this is a rather difficult conclusion for a soil mineralogist to accept, faced with feldspar grains under the SEM showing intensively etched but otherwise clean and sharp surfaces. Recent work by Teng (2004) on the dissolution of calcite in relation to saturation state and etch pit formation may help to reconcile these viewpoints. Using in situ fluid-cell AFM, Teng (2004) found that three different dissolution modes could be observed and related to saturation state. Two of these modes occurred near-equilibrium and far-from-equilibrium, where there was only a weak dependence of dissolution rate on dislocation density. In the near-equilibrium situation, no etch pit formation occurs and dissolution occurs at steps on the mineral surface. A sharp increase in etch pit formation occurs far-from-equilibrium, but this is uncontrolled in that it occurs in defect-free regions as well as along dislocations. Therefore, there is no significant relationship between dissolution rate and dislocation density far-from-equilibrium, the region where most experimental mineral weathering studies have been conducted. At intermediate saturation levels, however, dissolution takes place primarily at dislocations and along steps, so that dissolution rate should be more significantly related to dislocation density in this saturation range. So far as feldspars are concerned, it is not known whether the waters draining through saprolites and soils are typically in this intermediate saturation range where dissolution rate relates to dislocation density on exposed surfaces, but this must certainly be considered as a possibility.

The importance of micro-texture, in this case thin lamellae of albite in a host of K-feldspar (Fig. 5), as sites of dislocation and foci of dissolution was illustrated for an experimentally altered-microcline perthite by Wilson \& McHardy (1980). Similarly, 

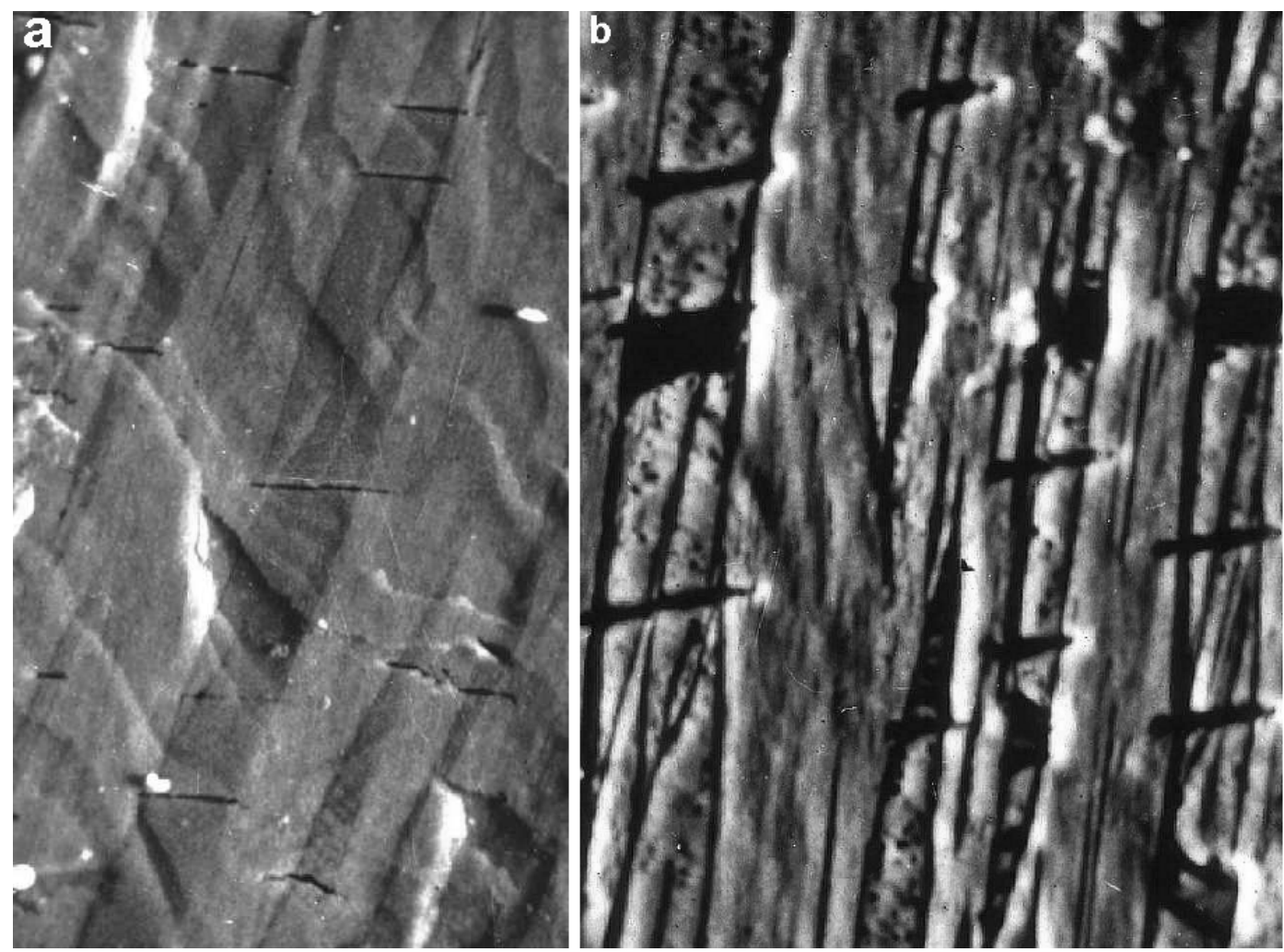

FIG. 5. (a) SEM ( $40 \mu \mathrm{m}$ wide) of the 010 surface of microcline-perthite after mild hydrothermal treatment showing perthitic lamellae transected by dislocations. (b) SEM (40 $\mu \mathrm{m}$ wide) of 010 microcline-perthite surface after further hydrothermal treatment showing selective etching of the perthitic lamellae (Wilson \& McHardy, 1980).

Inskeep et al. (1991) emphasized the susceptibility to weathering of Ca-rich exsolution lamellae, $\sim 700 \AA$ thick, relative to the more sodic phase in their TEM/XPS study of experimentally altered labradorite. This selective dissolution produced a corrugated surface and significantly affected the XPS analyses. Oxburgh et al. (1994) also surmized that the degree of exsolution in feldspars could greatly affect their dissolution rate. This relationship was explored in great detail by Lee \& Parsons (1995) for a perthitic alkali feldspar. This feldspar contained various types of micro-texture, including cryptoperthites made up of $<75 \mathrm{~nm}$ wide albite exsolution lamellae, lamellar micro-perthites with $>75 \mathrm{~nm}$ albite films, irregular patch perthites consisting of semi-coherent and coherent intergrowths of albite and microcline with significant micro-porosity. This micro-porous texture is present in unweathered grains and is a feature of deuteric or hydrothermal alteration. A striking innovative feature of the work of Lee \& Parsons (1995) is their use of a resin-impregnation technique to reveal the details of this micro-porosity and the way in which etch pits inter-connect beneath the mineral surface. They concluded that experimental dissolution of the perthitic alkali feldspar is primarily focused on edge dislocations of the perthitic lamellae and, in the case of natural weathering, on the perthitic lamellae themselves. Lee et al. (1998) later sought to reconcile the lack of correlation between dislocation density and experimental dissolution rate with the compelling SEM imagery showing that micro-texture and associated dislocations essentially control the progress of dissolution during natural weathering. It was concluded that this inconsistency could probably be accounted for by the differences in the saturation state of the weathering solutions in the laboratory and under natural conditions, as previously outlined. They attributed particular importance to dislocation 
density during the early stages of weathering and suggested that etching has a positive feedback effect in that it promotes the disintegration of the grains, exposing further reactive surface to weathering.

\section{Weathering rates of feldspar and surface area}

A compilation of experimentally derived dissolution rates for the main feldspar minerals was published by Blum \& Stillings (1996) and a selection of these data for dissolution at $\mathrm{pH} 3.0$ and 5.0 are shown in Table 4. These rates are consistent with the relative order of stability of the feldspar minerals to natural weathering as proposed by Goldich (1937).

However, the assumption that weathering rates of feldspar are proportional to exposed surface area is not necessarily true, as indicated by Holdren \& Speyer (1985). They considered that weathering occurred at selective sites of weakness and not over the grain surface as a whole, leading them to distinguish between a surface reaction-controlled mechanism and a surface area-controlled model. Holdren \& Speyer (1985) showed that dissolution rates of five different size fractions of an alkali feldspar, the specific surface area of which spanned a range of a factor of 20, varied by less than a factor of 2. They accounted for this lack of correlation by suggesting that reaction rate was

TABLE 4. Dissolution rates $(R=-\log$ mol felds $\mathrm{cm}^{2} \mathrm{~s}^{-1}$ ) of feldspar minerals at $\mathrm{pH} 3.0$ and 5.0 from data compiled by Blum \& Stillings (1996).

\begin{tabular}{lll}
\hline Mineral & $\mathrm{pH}$ & $R$ \\
\hline K-feldspar & 3.0 & 15.6 \\
& 5.0 & 16.6 \\
Albite & 3.0 & 15.5 \\
& 5.0 & 16.0 \\
Oligoclase & 3.0 & 15.4 \\
& 5.0 & 16.2 \\
Andesine & 3.0 & 14.6 \\
& 5.0 & 15.5 \\
Bytownite & 3.0 & 13.4 \\
& 5.0 & 14.8 \\
Anorthite & 3.0 & 10.0 \\
& 5.0 & 12.1 \\
\hline
\end{tabular}

controlled by the number of defects cropping out on the feldspar grain surface, and by the distances between these defects. In large grains this distance is much less than the size of the grain, so that if the density of defects per unit surface area remains constant over a range of grain sizes, then reaction rate will correlate with specific surface area. With decreasing grain size, eventually the distance between defects is the same or larger than the size of the mineral grain. In this case, no new defects are exposed and the relationship between dissolution rate and specific surface area will be lost. For similar reasons Anbeek $(1992,1993)$ also found that the larger particles of freshly ground and naturally weathered feldspars were more reactive than their finer-grained counterparts. These observations imply that some coarser particle sizes of feldspar could be more sensitive to weathering in soils than the finer grain sizes. Such a finding was made by Bain et al. (1994). They found that the plagioclase feldspar content of the coarse sand fraction $(200-2000 \mu \mathrm{m})$ decreased considerably from the $\mathrm{C}$ to the $\mathrm{A} / \mathrm{E}$ horizons in two podzolic soils whilst that of the fine sand fraction $(20-200 \mu \mathrm{m})$ remained constant (Table 5). The SEM observations showed that the coarse sand feldspars were more heavily etched.

\section{Weathering products of feldspar in saprolites and soils}

Experimental alteration of feldspars rarely yields crystalline clay mineral products such as are frequently found in the varied environments that occur in saprolites and soils. The most common products yielded by feldspar weathering are halloysite and kaolinite. Thus, Parham (1969a) showed that halloysite formed as a weathering

TABLE 5. Plagioclase feldspar (oligoclase) content (\%) in coarse sand $(200-2000 \mu \mathrm{m})$ and fine sand $(20-200 \mu \mathrm{m})$ fractions from basal and upper horizons in the Allt Mharcaidh catchment, Cairngorm Mountains, Scotland (Bain et al., 1994).

\begin{tabular}{lccc}
\hline Soil type & Horizon & Coarse sand & Fine sand \\
\hline Peaty podzol & Eg & 27 & 45 \\
& C & 40 & 46 \\
Alpine podzol & AehR & 23 & 51 \\
& C & 44 & 52 \\
\hline
\end{tabular}


product from orthoclase in weathered Hong Kong granite, possibly via an amorphous precursor (Parham, 1969b). Using SEM, Eswaran \& Bin (1978) also demonstrated that feldspar weathered primarily to halloysite in a weathered granite in Malaysia, but additionally showed that both halloysite and kaolinite could occur in the same feldspar pseudomorph. Robertson \& Eggleton (1991) showed that plagioclase feldspar in deeply weathered granite in Queensland was converted to kaolinite, which then altered to spiral halloysite rods through a process involving hydration. Jeong (1998) also observed co-existing kaolinite and halloysite in labradorite in a weathered anorthosite in Korea, but from SEM evidence interpreted the halloysite as forming ellipsoids and tubes on the plagioclase surface in the early stages of weathering. Globular aggregates of halloysite later formed and then coalesced to form stacked kaolinite plates.

Gibbsite too may be a product of feldspar weathering, even in its early stages in soils and saprolites. Thus, in a young montane soil developed on allivalite (an ultra-basic anorthite-olivine rock) on the island of Rhum, the clay fraction contained an abundance of gibbsite which could only have come from the feldspar (Wilson, 1969). Again, Tazaki (1976) found that gibbsite formed from plagioclase feldspar in relatively young weathered volcanic ash and Kawano \& Tomita (1996) observed that a mixture of halloysite and gibbsite formed on the early weathered surfaces of $\mathrm{K}$-feldspar in granitic rock in Yakushima Island, Japan. In both instances an amorphous precursor was involved.

Different weathering products may be formed from feldspar under more closed and alkaline conditions. For example, Wilson et al. (1971) showed that in granite and granulite cobbles in a deeply weathered boulder conglomerate in northeast Scotland, all the feldspars - orthoclase, orthoclase microperthite, albite and oligoclase - had transformed to a Cheto-type montmorillonite poor in $\mathrm{Fe}$. In this instance there appeared to be little or no structural control of the parent feldspar or evidence of a precursor amorphous phase. Again, Rodgers \& Holland (1979) investigated the weathering products of micro-cracked feldspar in tonalite cobbles from a morainic deposit in Montana. They found only kaolinite in orthoclase, whereas in oligoclase there was both kaolinite and smectite. They inferred from this that transport of solutes was sufficiently slow to allow concentration gradients to become established and for the system to reach equilibrium in accordance with theoretical activity diagrams.

It has often been asserted that illite is a common weathering product of feldspar in soils, but as yet there seems to be little unequivocal evidence to support this contention. Bearing in mind the higher temperatures and pressures necessary to form illite during the diagenesis of smectitic sediments, this is perhaps not surprising.

\section{Role of organic acids in feldspar weathering}

The role of organic acids in mineral weathering, particularly the implications for feldspar dissolution in soils, is still the subject of some debate. Huang \& Keller (1970) treated sand-sized grains of microcline and labradorite with weakly complexing acids $(0.01 \mathrm{M}$ acetic and aspartic acids) and strongly complexing acids $(0.01 \mathrm{M}$ salicylic and tartaric acids) and found that the solubilities of all cations were generally higher than in distilled water or $\mathrm{CO}_{2}$-charged water. Again, Huang \& Kiang (1972) investigated the dissolution of fresh plagioclase feldspars - albite, oligoclase, labradorite, bytownite and anorthite - in water and in various organic acids at $0.01 \mathrm{~m}$ concentration. They found that $\mathrm{Ca}-$ rich feldspars dissolved more readily in organic acids than water, but that the opposite was the case for the Na-rich feldspars. The effectiveness of organic acid dissolution was attributed to its ability to complex Al from the mineral. However, Manley \& Evans (1986) considered that the organic acid concentrations used in the above experiments were too extreme when compared with what are actually found in soils. They used $10^{-4} \mathrm{M}$ low molecular weight organic acids to dissolve labradoritic plagioclase feldspar, albite and microcline and found that, while citric and oxalic acid were the most effective of the organic acids used, the strength of the acid was more important than its ability to complex metals. Similarly, Mast \& Drever (1987) found that oxalic acid at concentrations up to $1 \mathrm{~mm}$ did not affect the rate of oligoclase dissolution and that dissolution rate was also independent of $\mathrm{pH}$ over the range 4 to 7 . In fact, Drever (1994) minimized the effect of organic acids on feldspar weathering, whether the acids are produced directly by land plants or indirectly following the decomposition of organic matter in soils. Laboratory experiments showed that for alkali 
feldspars oxalic acid had a negligible effect on dissolution rate, but that for anorthitic plagioclase feldspars dissolution rates increased by a factor of $\sim 2$ to 3. For labradorite and bytownite, Welch \& Ullman (1993) found that dissolution rates in organic acid solutions, particularly oxalic, citric, succinic, pyruvic and 2-ketogluconic acids, could be up to 10 times greater than the dissolution rates in mineral acids at the same $\mathrm{pH}$. The enhancement of ligand-promoted dissolution of $\mathrm{Al}$ and $\mathrm{Si}$ was particularly strong at near neutral $\mathrm{pH}$ values, probably due to the formation of strong bidentate chelates at the mineral surface. Similarly, the results of Stillings et al. (1996) for the dissolution of microcline, albite, oligoclase, andesine and bytownite in flow-through reactors in $1 \mathrm{~mm}$ oxalic acid solutions showed 2-15-fold increases compared with inorganic acids. This enhancement was especially marked in the $\mathrm{pH}$ range 5 to 6 . A review by Drever \& Stillings (1997) concludes that $1 \mathrm{~mm}$ oxalic acid shows feldspar dissolution effects ranging from none at all to enhancement by a factor of 15 , and that humic acids do not significantly affect feldspar dissolution. The effect of organic acids on feldspar weathering rates is thus considered to be rather small, with the possible exception of micro-environments immediately adjacent to roots and fungal hyphae.

Recently, van Hees et al. (2002) investigated the effects of naturally occurring soil organic acids on microcline and labradorite dissolution and found that at $\mathrm{pH} 5$ the rate increased from 2.4 to 5.7 times from aqueous dissolution at the same $\mathrm{pH}$, which was considered to be a significant enhancement. The evidence would appear to indicate, therefore, that organic acids such as oxalic and citric at the concentrations likely to occur in soils may increase the dissolution rates of feldspars, usually by less than an order of magnitude, through their ability to complex Al particularly around $\mathrm{pH} 5$. At lower $\mathrm{pH}$ values increased dissolution effects are more attributable to the higher proton concentration rather than the complexing nature of the acid. Calcium-rich plagioclase feldspars are more susceptible to attack by organic acids than K-feldspars by virtue of their higher $\mathrm{Al}$ content.

\section{Biological weathering of feldspars}

As realized by Drever (1994), the conclusions drawn by laboratory experiments may not necessarily apply to the specialized environment of the soil where mineral surfaces may be in direct contact with roots or fungal hyphae which may excrete organic acids at much higher concentrations than are found in drainage waters. Lichens represent convenient model systems where such close contacts between minerals and organic acid excreting organisms, in this case the mycobiont or fungal partner of the lichen symbiosis, may be studied easily. Jones et al. (1980) studied the weathering of basalt by the crustose lichen Pertusaria corallina and concluded that the labradorite-bytownite plagioclase feldspar in the rock was being etched directly by oxalic acid excreted from the mycobiont. They reasoned that accumulations of crystalline $\mathrm{Ca}$ oxalate at the lichen-rock interface resulted from this interaction, with the $\mathrm{Ca}$ being provided by feldspar. Similar observations were made following treatment of plagioclase feldspar with $0.5 \mathrm{M}$ oxalic acid and with the oxalic acid-producing-fungus Aspergillus niger. The link between the oxalic acid-producing mycobiont and substrate mineralogy was further reinforced by the finding of unusual and new oxalate minerals where lichens had weathered substrates of appropriate composition (Wilson et al., 1981; Wilson \& Jones, 1984; Purvis, 1984). In addition, lichen weathering also resulted in the formation of siliceous relics, aluminous silicate gellike material and poorly ordered $\mathrm{Fe}$ oxide minerals (Jones et al., 1980; Jones et al., 1981). However, later studies queried the role of oxalic acid in lichen weathering of feldspars and other rock-forming minerals. Thus, Barker \& Banfield (1996) investigated the weathering of amphibole syenite by Rhizocarpon grande and Porpidea albocaerulescens and could find no evidence of "pervasive leaching" of feldspars or other minerals, all of which remained perfectly intact in the lichen thallus, or of the existence of siliceous relics such as were identified by Wilson et al. (1981). They attributed what biologically mediated weathering there was, to extracellular organic polymers, most likely acidic mucopolysaccharides, and argued against the role of lichen and oxalic acid as important weathering agents. Further, they implied that the siliceous relics observed by Wilson et al. (1981) could have been artefacts of the preparation procedure. These various findings and interpretations may quite possibly be accounted for by the fact that different lichens were being studied. In fact, not all lichens are able to excrete metal-complexing organic acids and sometimes lichens may actually reduce weath- 
ering rates. Lee \& Parsons (1999) in their study of weathering by Rhizocarpon geographicum on Shap granite concluded that the alkali feldspars beneath the lichen, although extensively etched, had most likely been subjected to non-biochemical weathering before lichen colonization. Further, they observed silica-rich material similar to that found by Wilson et al. (1981) but concluded that this could actually help to retard weathering by the lichen. Wilson (2004) also drew attention to work describing the protective effect of some lichens to destructive weathering of ancient stonework.

Further evidence for the efficacy of microbial extracellular polysaccharides in weathering plagioclase feldspar (bytownite) was provided by Barker et al. (1998) who showed that release of $\mathrm{Si}$ and $\mathrm{Al}$ was increased by up to 2 orders of magnitude in batch reactors to which bacteria were added, compared with inorganic controls. In many cases the grains were covered by biofilms, the mineral surfaces appearing to be more extensively etched beneath these biofilms. Again, Welch et al. (1999) made similar observations with respect to an enhancement of plagioclase feldspar dissolution when the mineral was reacted with solutions of acid polysaccharide, although at neutral $\mathrm{pH}$ these substances inhibited release of $\mathrm{Si}$ and $\mathrm{Al}$. It is uncertain at present whether these findings can be applied to natural environments because, as pointed out by Welch et al. (1999), water is unlimited in batch reactors but restricted and episodic in lichens.

Although the lichen-rock relationship does represent a convenient model for understanding microbially mediated mineral weathering in the soil rhizosphere (Barker \& Banfield, 1998; Banfield et al., 1999), increasingly, efforts are being made to characterize the nature of feldspar weathering within the rhizospheric soil itself. In part, this is due to the realization that higher plants are capable of markedly enhancing weathering rates. Thus, Cochran \& Berner (1996) found that vascular plants on Hawaiian basaltic lava flows increased weathering rates by at least a factor of 10 when compared with unvegetated or lichenized flows. The dissolution of plagioclase feldspar accounted for most of these increased rates. Lichenized Hawaiian basalts weather more quickly than where these rocks were not colonized (Brady et al., 1999), but only by a factor of $\sim 2$. Moulton et al. (2000) found that plagioclase feldspar in a vegetated catchment developed on tholeiitic lava flows in Iceland weathered twice as quickly as plagioclase in an unvegetated catchment. Such enhanced weathering suggested a major role for plants in lowering atmospheric $\mathrm{CO}_{2}$ in geological history.

The weathering of feldspars by mycorrhizal fungi has became a subject of some debate since the paper of Jongmans et al. (1997) on rock-eating fungi. They described tunnel-like features within feldspar and hornblende grains in forest soils, some of which were colonized by fungal hyphae. Jongmans et al. (1997) hypothesized that the tunnels were actually formed by ectomycorrhizal fungi which were capable of dissolving the mineral by virtue of excreting organic acids. The feldspars thus acted as the direct source of mineral nutrients to forest trees (van Breemen et al., 2000; Landeweert et al., 2001). However, another interpretation could be that the fungal hyphae were fortuitously occupying these spaces within the feldspar grains and that these tunnels, therefore, pre-date weathering. The existence of such features in fresh feldspars is well documented by Lee et al. (1998). Furthermore, Wallander \& Wickman (1999) could find no evidence that ectomycorrhizal fungi in Pinus sylvestris could effectively mobilize $\mathrm{K}$ from microcline in a pot study, although the duration of experiment was rather short (33 weeks). On the other hand, Hoffland et al. (2002) showed that the intensity of tunnelling in feldspar grains increased with the age of the soil in a podzol chronosequence, the implication being that the tunnels were being formed during weathering and that the fungal hyphae within the tunnels demonstrate a causal relationship.

\section{WEATHERING OF MICAS}

A huge amount of work has been done on weathering of mica minerals because of their importance as a potential source of $\mathrm{K}$ in the soil for plants. It has long been known that there was a sharp contrast in the susceptibility to weathering of biotite compared with muscovite. Biotite weathers very easily and may progress to advanced stages even at the base of the weathering profile. Thus, the mineral may be converted directly to kaolinite and earlier and less extreme transformations, such as vermiculitization, may be bypassed altogether. In contrast, muscovite is often extremely resistant to weathering and may persist unaltered to the top of the weathering profile, even in the old soils. In this review, therefore, it is more convenient to consider 
mica weathering in terms of degree of alteration of the structure rather than the position of the mineral in the weathering profile.

\section{Vermiculitization of mica}

The vermiculitization reaction is the simplest form of biotite weathering and merely involves exchange of the interlayer $\mathrm{K}$ of the mica for ions of the external solution. Otherwise, complete structural integrity is maintained (Barshad, 1948). This reaction is a diffusion-controlled process and can be accomplished easily in the laboratory (RausellColom et al., 1964), although whether it proceeds will depend, amongst other things, on the concentration of $\mathrm{K}$ in the external solution (Martin \& Sparks 1985). The critical solution K concentrations at $25^{\circ} \mathrm{C}$ for the vermiculitization of $10-20 \mu \mathrm{m}$ size flakes of biotite and muscovite in $\mathrm{NaCl}$ were found to be 11 and $0.1 \mathrm{mg} / \mathrm{l}$, respectively (Scott \& Smith 1966; Newman 1969). At higher K levels the vermiculitization reaction would stop, providing one possible reason as to why muscovite is so much less susceptible to weathering than biotite.

The natural weathering of biotite has been studied intensively since the classic work of Walker (1949), focusing particularly upon the vermiculitization process itself, as well as associated aspects such as oxidation of octahedral $\mathrm{Fe}$, the mechanism involved in the reduction of layer charge, the development of interstratified structures, and conversion of biotite to 'chlorite' or smectite.

In the laboratory, vermiculitization of micas at levels of $\mathrm{K}$ below equilibrium concentrations can be maintained in the external solution by precipitating the $\mathrm{K}$ as an insoluble compound such as potassium tetraphenylboron (Reed \& Scott 1962). Using this method of vermiculitization, Raman \& Jackson (1965) and Newman \& Brown (1966) observed that the alteration process proceeded not only from the edges of the flakes, but also by penetration along cracks and other defects normal to the basal plane. Another complicating factor with respect to the diffusion control model is the effect of particle size. Mortland \& Lawton (1961) found that K released from biotite in $\mathrm{NaCl}$ solutions was slower from fine particles than from large ones and Reichenbach \& Rich (1969) made a similar observation with respect to muscovite following exchange with $\mathrm{BaCl}_{2}$ at elevated temperatures. They proposed that this effect was related to differences in the exchange mechanism brought about by splitting of the particles. This effectively released the stress brought about by expansion and bending of the flakes following $\mathrm{K}$ depletion of the layers from the flake edge, resulting in inhibition of further $\mathrm{K}$ exchange.

In the natural vermiculitization of biotite, the process frequently involves the formation of hydrobiotite, a regularly interstratified biotitevermiculite yielding a basal spacing of $\sim 24 \AA$ (Coleman et al., 1963; Wilson, 1970). This interstratification is brought about when $\mathrm{K}$ is removed from every other layer in the biotite structure and implies that there is some mechanism by which $\mathrm{K}$ is preferentially retained in the layers adjacent to the vermiculitized layers. A plausible reason for this was proposed by Norrish (1973), who suggested that the regular interstratification was due to the inclined hydroxyl orientation in these adjacent layers, thus placing the $\mathrm{K}$ ions in these layers in a more negative and more stable environment. Bassett (1960) had earlier proposed that the reason why phlogopite and biotite were more susceptible to the vermiculitization than muscovite was the perpendicular orientation of the dipole moments of the hydroxyl ions in the trioctahedral micas, compared with the oblique orientation of these dipole moments in the dioctahedral mica.

The natural vermiculitization of biotite involves not only the replacement of interlayer $\mathrm{K}$ by other cations but other structural changes too, in particular the oxidation of octahedral ferric ion. This was noted by Walker (1947) in the early stages of biotite weathering in some Aberdeenshire soils and was later thought to be one of the mechanisms by which layer charge was reduced during the vermiculitization process (Newman \& Brown, 1966). However, the two processes $-\mathrm{Fe}^{2+}$ oxidation and vermiculitization - do not keep in step, the former occurring early in the weathering process and the latter increasing progressively as the weathering proceeds. Some other mechanism is required, therefore, to reduce layer charge (Scott \& Amonette, 1988). The ejection of $\mathrm{Fe}$ from the octahedral sheet of biotite following oxidation is one such mechanism for which there is good evidence in both laboratory and naturally vermiculitized biotite. Farmer et al. (1971) presented infrared and other evidence showing that octahedral $\mathrm{Fe}$ was irreversibly lost during experimental vermiculitization of biotite, forming amorphous 
interlayer oxides, and that the number of octahedral sites in the structure increased considerably. Scott \& Amonette (1988) considered that cation ejection accounts for most of the reduced layer charge observed during vermiculitization of biotite and that there is no need to invoke deprotonatation from hydroxyls as an additional mechanism. The fact that oxidation of biotite does not necessarily proceed in tandem with vermiculitization is shown by the occurrence of oxybiotites after natural and experimental alteration (Gilkes et al., 1972).

In fact, the oxidation of octahedral ferrous $\mathrm{Fe}$ in biotite may be an important factor in the ability of the mineral to retain its interlayer $\mathrm{K}$, as was earlier pointed out by Barshad \& Kishk (1968). Convincing experimental evidence for the influence of oxidation state on release of interlayer $\mathrm{K}$ from biotite to salt solutions, and on overall dissolution rates of biotite in acidic solutions, was provided by Gilkes et al. (1973a,b). The capacity of biotite to retain most of its interlayer $\mathrm{K}$ in weathered soils (Denison et al., 1929) and in sediments deposited in oxidizing conditions, such as the Old Red Sandstones (Wilson \& Duthie, 1981), may also be accounted for by the oxidation state of the mineral. Recent work by Jeong \& Kim (2003) confirms that biotite can be almost completely oxidized in a weathering profile and yet retain most of its $\mathrm{K}$ in a $10 \AA$ structure. The occurrence of trioctahedral illite in soil clays is consistent with such observations (Fordham, 1990a).

Nevertheless, active oxidation may also play an essential role in the vermiculitization process as is shown by the formation of hydrobiotite. Thus, a biotite which weathered naturally to hydrobiotite (Wilson, 1970) could be altered to hydrobiotite in the laboratory only under oxidizing conditions (Farmer \& Wilson, 1970). Gilkes (1973) also found that oxidation of structural iron in biotite and removal of $\mathrm{K}$ from alternate layers led to formation of hydrobiotite during experimental vermiculitization.

The vermiculitization of biotite may not necessarily proceed through a hydrobiotite stage but in this case it still involves depletion of $\mathrm{K}$ from some preferred layers which are always bounded by other layers which are not K-depleted (Banfield \& Eggleton, 1988). Using TEM these authors sometimes observed a long-range regularity, where vermiculite layers were separated by 4 to 5 biotite layers, and argued that such an arrangement could not be accounted for by a change in hydroxyl orientation such as probably occurs with hydrobiotite. This long-range regularity was suggested as being a reflection of the distance of dissipation of the stress field set up by an initially vermiculitized layer.

The vermiculitization of biotite can occur at any stage of the weathering profile and may involve other structural changes in addition to those described above. Thus, Moon et al. (1994) provided evidence to show that the loss of layer charge during the vermiculitization of phlogopite involved loss of Al from the tetrahedral sheet and progressive increase in $\mathrm{Al}$ (replacing $\mathrm{Fe}^{2+}$ and $\mathrm{Mg}$ ) in the octahedral sheet during the early stages of weathering. A similar mechanism was earlier proposed by Fordham (1990b) to explain the conversion of biotite to dioctahedral clay minerals in a soil developed on granite gneiss. Both dioctahedral vermiculite and smectite-like minerals were identified primarily on the basis of electron probe microanalysis, the qualification 'like' being necessary because of the uncertainty involved in identifying clay minerals in this way. However, smectites may certainly form as a consequence of biotite weathering as concluded by Ismail (1969, 1970) under arid and alkaline conditions and Kapoor (1972) under humid acidic conditions. Earlier, MacEwan (1954) described trioctahedral smectite derived by weathering of biotite in poorly drained soils.

\section{Kaolinization of micas}

It should perhaps be emphasized that vermiculitization may be bypassed under more intensive weathering conditions and conversion of biotite directly to kaolinite may occur (De Kimpe \& Tardy, 1968). In fact, biotite may be completely pseudomorphed by kaolinite (Mitsuda, 1960) and this transformation may take place within a few centimetres of fresh rock (Eswaran \& Heng, 1976). Optical observations of kaolinized biotite often suggest an orientation relationship between the two phases and this was confirmed by single crystal X-ray photographs (Wilson, 1966; Tzuzuki et al., 1968). An epitaxial origin for the oriented kaolinite, where the biotite basal surface acts as a template for kaolinite growth, was suggested by Wilson (1966) and by Banfield \& Eggleton (1988), but other works indicate that a topotactic origin involving complete kaolinite replacement of the biotite is also feasible (Gilkes \& Suddhiprakarn, 
1979a,b; Harris et al., 1985a,b; Rebertus et al., 1986; Ahn \& Peacor, 1987). Recent work seems to confirm the viability of these different modes of origin. Thus, Dong et al. (1998) provided TEM evidence to show that a single layer of biotite altered to two layers of kaolinite. On the other hand, Jeong $(1998,2000)$ showed that the weathering of biotite to kaolinite involved up to a 9-fold volume increase, suggesting an extraneous source of the Al (and presumably $\mathrm{Si}$ ) and growth of kaolinite on templates provided by the biotite basal surfaces. It would be logical to think that the kaolinite associated with exfoliated flakes of muscovite also forms by an epitactic mechanism, but TEM and analytical evidence favour a topotactic origin in two instances (Robertson \& Eggleton, 1991; Singh \& Gilkes, 1991).

\section{Multi-component weathering products of biotite}

Many weathered biotite flakes, which may or may not be vermiculitized, consist of a multicomponent mineral complex involving halloysite (Eswaran \& Heng, 1976; Kretzschmar et al., 1997), gibbsite (Wilson, 1966; Tsuzuki et al., 1968; Jolicoeur et al., 2000) and goethite (Eswaran \& Heng, 1976; Gilkes \& Suddiprakarn, 1979a,b; Banfield \& Eggleton, 1988). Halloysite appears to have grown preferentially on the biotite cleavage surfaces but there is no indication of a strong orientation relationship. Gibbsite too, although oriented parallel to the basal cleavage of biotite, is randomly oriented in the $a b$ plane (Tsuzuki et al., 1968). These observations suggest that both minerals are formed as a result of crystallization from solutions not necessarily directly connected with the weathering of biotite itself, although Jolicoeur et al. (2000) interpret SEM evidence as indicating topotactic formation of halloysite from biotite. In contrast, both Gilkes \& Suddiprakarn (1979b) and Banfield \& Eggleton (1988) report that goethite may occur as oriented laths on the biotite surfaces indicating that the surface influences the orientation of the $\mathrm{Fe}$ oxide mineral, although both sets of authors conclude that this does not necessarily indicate an epitaxial relationship. However, in all probability, the source of the $\mathrm{Fe}$ must at least in part be attributed to the ejection from the biotite structure of octahedral $\mathrm{Fe}$ following oxidation, as suggested by Eswaran \& Heng (1976).

\section{Weathering of micas in the soil}

All the processes and products of weathering discussed so far can occur in any stage of the fully developed weathering profile. However, in the soil, micas may weather in a way that seems to be specific to this environment. Dioctahedral micas, for example, may be depleted of interlayer $\mathrm{K}$ to yield what is essentially a dioctahedral analogue of vermiculite, a mineral first described from British soils by Brown (1953). Dioctahedral vermiculite is almost always confined to soil clay fractions and occurs particularly in intensively weathered soils such as Ultisols, Alfisols and even Oxisols. It has rarely, if ever, been identified as a weathering product of muscovitic mica in the saprolite or weathered rock parts of weathering profile. The reason for this may be that vermiculitization of dioctahedral mica can only take place from exceedingly thin crystals like those described from soils (Robert et al., 1991). Particle microdivision has been shown to be an important part of the micaweathering process in soils (Romero et al., 1992; Aouidjit et al., 1996) and there is evidence that with decreasing grain size the $2 M_{1}$ muscovite may convert to the $1 M d$ polytype (Martin-Garcia et al., 1997). Aoiudjit et al. (1996) presented HRTEM evidence to show that vermiculitization of muscovitic mica occurred in very fine particles. They showed micrographs of particles with a muscovite core and a 15 layer-thick vermiculitic rim, as well as muscovite-derived vermiculite consisting of 2 to 5 layers in thickness. Finegrained dioctahedral vermiculite may therefore be susceptible to vermiculitization in the soil because of its higher specific surface and enhanced reactivity. However, this concept is inconsistent with the experimental data of Reichenbach \& Rich (1969) which suggests that muscovitic mica retains its interlayer $\mathrm{K}$ more tenaciously with decreasing grain size.

It may be noted that a dioctahedral analogue of hydrobiotite has also been described from some soil clay fractions, where it clearly derives from the weathering of dioctahedral mica (Churchman, 1978, 1980). A regularly interstratified rectoritic mineral was also obtained from the alteration of sericite by Tomita (1977). In these instances the mechanism involved in the origin of the regular interstratification remains to be elucidated, but it is clearly not likely to involve the oxidation of octahedral ferrous $\mathrm{Fe}$. 
More usually, dioctahedral soil vermiculites are converted to interlayered or intergradient minerals due to the introduction of non-exchangeable hydroxy-Al polymers into the interlamellar space. The aluminous material may derive directly from the decomposition of the tetrahedral or octahedral sheets within the mineral structure, or indirectly from the weathering of other aluminous components such as feldspars. Al-hydroxy interlayered vermiculites are exceedingly common in acidic soils, e.g. April et al., (1986) and Karathanasis, (1988), the stability of the interlayer material being favoured by the $\mathrm{pH}$ range 4.0-5.8 approximately (Barnhisel \& Bertsch, 1989). The $\mathrm{pH}$ dependency of the interlayers of dioctahedral vermiculite in some Scottish podzolic soils was demonstrated by Bain et al. (1990), complete removal being detected in E-horizons where $\mathrm{pH}$ fell below 4.3.

Although most Al-interlayered vermiculites are dioctahedral, trioctahedral vermiculites resulting from biotite weathering can also be interlayered in the same way. This was first shown by Kato (1965) in Japan and by Wilson (1966) in Scotland and has since been described in Piedmont soils in the USA (Rebertus et al., 1986; Jolicoeur et al., 2000).

\section{Biological weathering of micas}

Biotite can also weather in the soil as a direct result of uptake by plants of interlayer $\mathrm{K}$ or by decomposition by organic acids excreted by plant rootlets, fungi or bacteria. Mortland et al. (1956) showed that fresh biotite, applied as the sole source of $\mathrm{K}$ in a pot experiment with wheat, was almost completely vermiculitized to a $14 \AA$ structure, a transformation accompanied by depletion of total $\mathrm{K}$ (5.8 to $2.8 \%$ ) and an increase in CEC (11 to $54 \mathrm{mEq} / 100 \mathrm{~g}$ ). A similar result was obtained by Spyridakis et al. (1967) when coniferous and deciduous tree seedlings were grown over a 13 month period in sand cultures with biotite as a sole source of $\mathrm{K}$ and $\mathrm{Mg}$. Additionally, they claimed that most of the species tested produced kaolinite. However, while the XRD evidence for identifying the clay mineral is convincing, it is notable that such rapid formation of kaolinite has never been found by other researchers. (A possible explanation for the results of Spyridakis et al. (1967) is that the sand used for their experiments may itself have been contaminated with kaolinite).

The direct effect of fungal species on weathering of micas was tested by Weed et al. (1969). In the experimental system used they found that biotite could be completely vermiculitized, where the fungi acted merely as $\mathrm{K}^{+}$sinks and where $\mathrm{K}$ was exchanged for $\mathrm{Na}$ in external solution. There was even a small but significant vermiculitization of muscovite. Where the fungi were in direct contact with the micas, K-depletion of the minerals was not so marked but was still easily observable. The effect of soya bean mycorrhizal fungi on biotite weathering was shown by Mojallali \& Weed (1978) to promote vermiculitization which occurred particularly at the edge of sand-sized flakes. However, in addition to depletion of $\mathrm{K}$ there was also a loss of $\mathrm{Al}$ and $\mathrm{Si}$, suggesting a more drastic structural rearrangement. Complete breakdown of biotite to an amorphous product following inoculation by Aspergillus niger was reported by Boyle et al. (1967) and was attributed to the production of oxalic and citric acid. Mycorrhizal weathering of biotite on Pinus sylvestris seedlings grown in pot experiments using forest soils was also attributed to oxalic and citric acids excreted by the fungus (Wallander \& Wickman, 1999; Wallander, 2000).

The ability of the mycobiont associated with some crustose lichens to completely convert a trioctahedral mica to a siliceous relic through the complexing action of oxalic acid was suggested by the work of Wilson \& Jones (1983). However, Leyval \& Berthelin (1991) reported greater K losses from phlogopite when Pinus sylvestris was inoculated with acid-producing bacteria (Agrobacterium $s p$.) compared with inoculation of a mycorrhizal fungus (Laccaria laccata). Nevertheless, greater K losses occurred where the phlogopite was closely associated with the mycorrhizae, although that was not attributed to acid production.

\section{Rates of weathering of micas}

With regard to the rates of weathering of micas, there is a difficulty in making comparisons with the other main rock-forming minerals because typically the trioctahedral micas do not dissolve stoichiometrically in aqueous acidic solutions. For example, Acker \& Bricker (1992) found that in the $\mathrm{pH}$ range 5.0 to $5.5, \mathrm{Mg}$ is the only cation detected in substantial amounts in the altering solutions, indicating attack on the octahedral sheet and no significant dissolution of tetrahedral sheet. At lower $\mathrm{pH}$ values there are indications that the whole of the biotite structure begins to decompose, but still incongruently. It is only at $\mathrm{pH} 3$ that increasing $\mathrm{Si}$ 
and $\mathrm{Al}$ concentrations indicate significant decomposition of the tetrahedral sheet, with increasing $\mathrm{Mg}$ and $\mathrm{Fe}$ concentrations showing further attack on the octahedral sheet. Even at $\mathrm{pH} 1$ the dissolution of biotite is incongruent and anisotropic, with the edge surfaces being attacked in preference to the basal surfaces (Turpault \& Trotignon, 1994). These authors found that short-term leaching occurred in the order $\mathrm{K}$ (interlayer) $>\mathrm{Fe}, \mathrm{Al}>\mathrm{Mg}$ (octahedral layer) $>\mathrm{Si}$ (tetrahedral layer). Acker \& Bricker (1992) suggested that at $\mathrm{pH} 4$ the dissolved ion ratios were consistent with the formation of a vermiculitic product where tetrahedral $\mathrm{Al}$ was conserved and where substantial amounts of interlayer $\mathrm{K}$ and octahedral $\mathrm{Mg}, \mathrm{Fe}$ and $\mathrm{Al}$ were released. Such a product has previously been described in a natural weathering profile by Velbel (1985). Further, Acker and Bricker determined octahedral dissolution for biotite at $\mathrm{pH} 6.7$ at $3.9 \times 10^{-12} \mathrm{moles} / \mathrm{m}^{2} \mathrm{~s}^{-1}$. This rate was some 30 times higher than that determined by Velbel (1985) which was calculated by geochemical mass-balance where the $\mathrm{pH}$ of the natural waters was $\sim 6$. At $\mathrm{pH} 5$ the octahedral dissolution rate determined by Acker and Bricker was $9.1 \times 10^{-12}$ moles $/ \mathrm{m}^{2} \mathrm{~s}^{-1}$, which is quite similar to the rates found later at this $\mathrm{pH}$ for both biotite and phlogopite by Kalinowski \& Schweda (1996). These authors also found that dissolution of muscovite in the $\mathrm{pH}$ range 1 to 4 was close to stoichiometric, but two orders of magnitude slower than the trioctahedral micas.

\section{WEATHERING OF CHLORITES}

\section{Transformations in weathered rock}

The alteration of chlorite in deeply weathered rock was investigated by Murakami et al. (1996) and Banfield \& Murakami (1998). The alteration described was in a deeply weathered quartz mica schist associated with a secondary uranium ore deposit in Northern Territory, Australia. Murakami et al. (1996) found that chlorite progressively converted to vermiculite, through chlorite-vermiculite intergrades and interstratifications, and ultimately to kaolinite and fine-grained $\mathrm{Fe}$ oxide. The vermiculitization process is characterized by a depletion of $\mathrm{Fe}$ and $\mathrm{Mg}$ and by a slight loss of Al. This process was studied in further detail by Banfield \& Murakami (1998) using atomic-resolution TEM. Their evidence suggested vermiculitization by a continuous solid-state mechanism involving, therefore, non-stoichiometric and preferential dissolution of the brucite sheet. It was proposed that there was a tendency for every second brucite sheet to be removed leading to a semi-regularly interstratified vermiculite-chlorite. This process developed through a change to a lower energy IIa stacking arrangement of the vermiculitized interlayer, thus increasing the stability of adjacent interlayers because of reduced repulsion between the interlayer cations and the adjoining tetrahedral sheets. The oxidation and ejection of $\mathrm{Fe}$ from octahedral sites in order to reduce layer charge, as in the biotite to vermiculite transformation, was not thought to be involved in the process. Aspandiar \& Eggleton (2002a,b) also described the topotactic conversion of chlorite to a regularly interstratified chlorite-vermiculite (corrensite) in weathered basaltic rock and invoked a similar mechanism to account for the stacking arrangement. It should be noted, however, that all the above studies involved weathering of hydrothermally altered rock. In these circumstances and bearing in mind the occurrence of interstratified chloritic minerals in meta-basalts (Shau et al., 1990) and even vermiculite-like minerals in lowgrade metamorphic sequences (Ruiz Cruz, 1999), it is obviously prudent to distinguish unequivocally between the effects of hydrothermal alteration and those of weathering.

\section{Weathering in saprolite}

In the saprolite, chlorite weathering continues to proceed by vermiculitization but also involves the formation of other minerals with increasing weathering intensity. Gilkes \& Little (1972) demonstrated that vermiculitization of chlorite in a profile on weathered phyllites was accompanied by oxidation of ferrous iron and loss of $\mathrm{Fe}$ and $\mathrm{Mg}$ from the brucite sheet. Vermiculitization of chlorite in an amphibolite saprolite was also shown by Proust (1982). In this instance the vermiculite phase tended towards dioctahedral composition and was accompanied by kaolinite at grain contacts. Further evidence for the formation of a dioctahedral interstratified vermiculite phase derived from chlorite weathering in both weathered rocks and saprolite was provided by Proust et al. (1986). They concluded that vermiculitization did not proceed by oxidation of $\mathrm{Fe}^{2+}$ but by simultaneous leaching of $\mathrm{Fe}^{2+}$ and $\mathrm{Mg}$ from the brucite sheet with concomitant enrichment of $\mathrm{Si}$ and $\mathrm{Al}$. With 
further weathering, however, vermiculitized chlorite converts to a mixture of kaolinite and iron oxide minerals as found by Murakami et al. (1996) and Aspandiar \& Eggleton (2002a,b). The latter authors proposed that the nature of microsites in the weathered rock and saprolite, within which the chlorite occurred, profoundly influenced the mechanism of weathering and the sequence of secondary products. Where the fabric and texture of the rock had been largely preserved and where few solution passageways had developed, then topotactic and epitaxial reactions occur, even where vermiculite converts to kaolinite and where direct structural inheritance is not possible. On the other hand, where micro-fissures create solution passageways within the regolith unit, then the inheritance of structure and chemistry from the weathering primary mineral to the secondary product is at a minimum and a dissolution-precipitation mechanism must predominate involving a variety of extraneous sources.

\section{Weathering in soils}

In soils, chlorite may yield a variety of weathering products some of which are similar to those found in weathered rock and saprolite. Thus, Johnson (1964) showed that a regularly interstratified vermiculite-chlorite weathered from chlorite in a soil profile developed upon metamorphosed basalt in Pennsylvania. The regular interstratification was suggested as being due to the original structure of the parent chlorite where alternate brucite interlayers were linked to adjacent tetrahedral sheets by bonds of different strength. However, the fact that even the apparently unweathered chlorite yielded a high spacing $(29 \AA)$ on the XRD diagram indicates that the chlorite was already interstratified to some extent in the meta-basalt, possibly as a result of hydrothermal alteration as proposed by Shau (1990). The experimental formation of regularly interstratified chlorite-vermiculite was achieved by Makumbi \& Herbillon (1972) and by Ross \& Kodama (1976), both sets of workers emphasizing the role of irreversible oxidation. However, it should be noticed that both studies involved original chloritic material that may already have contained some expansible layers. Thus, Herbillon \& Makumbi (1975) record traces of vermiculite or interstratified vermiculite-chlorite in the fresh chlorite schist that they used and the material used by Ross \& Kodama (1976) was from a chloritic meta-basalt similar to the parent material in the soils studied by Johnson (1964). Structural control was again invoked to account for the regularity of the interstratified structure, although Ross \& Kodama $(1973,1976)$ showed that the same chlorite polytype can yield different products.

Complete vermiculitization of chlorite has been suggested as occurring in podzolic soils in Wales developed on chlorite-mica mudstones and phyllites (Adams, 1976; Adams \& Kassim, 1983). However, these chlorites may be unusual as Evans \& Adams (1975) provided chemical evidence to show that the chlorites in the parent material may contain both dioctahedral and trioctahedral layers. The weathered chlorites in Canadian podzols studied by Ross et al. (1982) showed a change towards a dioctahedral structure concomitant with vermiculitization, loss of $\mathrm{Al}$ and $\mathrm{Fe}$ and crystallization of goethite. In Canadian Alfisols, Ghabru et al. (1990) proposed that an Fe hydroxy interlayer vermiculite weathered from chlorite. In acidic lignitic shales, Senkayi et al. (1981) found that chlorite ultimately transformed into a smectite following dissolution of an Fe-rich interlayer hydroxide sheet. Carnicelli et al. (1997) described the transformation of a ferruginous chlorite to dioctahedral smectite in a podzol profile where there was so little illite that this mineral could not have been the source for the smectite. The various weathering products identified in these studies emphasize the importance of thoroughly characterizing the nature of the original chlorite itself.

With more intensive weathering in the soil, the vermiculitization stage of chlorite decomposition may be completely bypassed. Thus, chlorite weathering in some Korean forest soils resulted in the formation of a mixture of tubular and crumpled lamellar halloysite along with fine-grained goethite and hematite (Cho \& Mermut, 1992). In the acidic conditions common in the organic horizons of podzols chlorite may be completely dissolved with no intermediate product other than goethite (Bain, 1977; Ross et al., 1982; Bain \& Duthie, 1984). This is consistent with the stoichiometric dissolution of chlorite in mineral acids found by Ross (1968, 1969) and Malmström et al. (1996), as well as the lack of vermiculitic product found after leaching with fulvic acid (Kodama et al., 1983). However, a recent investigation by Hamer et al. (2003) on the dissolution of ripidolite ( $\mathrm{Mg}$-Fe-chlorite) in organic and inorganic acids showed that the process was non-stoichiometric at low proton and ligand 
concentrations, with preferential release of $\mathrm{Si}$ relative to $\mathrm{Al}$ and $\mathrm{Fe}$. For mineral acids at higher concentrations, dissolution becomes almost stoichiometric but non-stoichiometry is still maintained in the case of oxalic and citric acids. For the former there is preferential release of $\mathrm{Al}$ and $\mathrm{Fe}$ relative to $\mathrm{Si}$ and for the latter of Fe. The organic acids enhance dissolution relative to inorganic acids by a factor of $\sim 3$. The $\log$ of dissolution rates of the chlorite studied at $\mathrm{pH} 4.5$ is $\sim 10^{-12}$ moles $\mathrm{m}^{2} \mathrm{~s}^{-1}$ which is similar to the dissolution rate of biotite.

\section{CONCLUSIONS}

The processes, products and rates of weathering of the primary rock-forming minerals (with the exception of quartz) have been reviewed in the context of the different conditions characteristic of the fully developed weathering profile. In the special closed and near-equilibrium environment in weathered rock at the base of the profile, olivine, pyroxene, amphibole and chlorite have been found to transform largely by a solid-state topotactic mechanism to pseudomorphs of oriented expansible trioctahedral clay minerals (smectites, vermiculites and interstratified minerals), in addition to $\mathrm{Fe}$ oxide minerals (goethite and hematite). Orientation relationships show that there is a close structural relationship between the host mineral and the weathering product. However, in many instances the weathered rock has also been hydrothermally altered, so that it is often not clear that the changes described can be wholly attributed to weathering. Because of the possibility that even slight hydrothermal alteration may predispose a mineral to weather along an already established pathway, it is obviously prudent to characterize the nature of the primary mineral as thoroughly as possible and to ensure that it is completely fresh. In any event, the trioctahedral clay minerals forming at the base of the weathering profile are usually ephemeral and seldom persist in the more open and far-fromequilibrium conditions characteristic of most saprolites and soils. In addition, the reactions occurring in weathered rock can only take place at micro-sites to which water has access via microcracks and other passageways, so that only a proportion (possibly a small proportion) of a particular mineral may be affected in this way. Further, once the weathered rock disaggregates to saprolite at the base of the weathering profile then the primary minerals are exposed to a more open environment and the solid-state reaction described above may be bypassed altogether. With regard to the decomposition of feldspar in weathered rock, there is little evidence that the clay minerals formed bear a close structural relationship with the parent mineral, which is understandable bearing in mind the drastic rearrangement that must be involved in the conversion of a framework- to a layer-structure. The bulk of the evidence indicates that in weathered rock the formation of clay minerals, usually smectitic or halloysitic, from feldspars involves the precipitation of a precursor amorphous phase, although this is not necessarily the case in saprolite.

The saprolite at the base of the weathering profile is often completely physically disaggregated but altered chemically to only a minor extent. At this stage, the environment is relatively open, allowing the free passage of drainage waters the chemistry of which is influenced by reactions higher up in the profile and with weathering of individual minerals taking place in a far-from-equilibrium situation. Here the weathering products formed in weathered rock may undergo further more drastic transformations, usually involving the formation of a complex of kaolinitic and $\mathrm{Fe}$ oxide minerals, and fresh mineral surfaces are exposed to aqueous dissolution processes for the first time. Such fresh mineral surfaces may continue to be exposed to weathering higher up in the saprolite and even in the soil. It is in these circumstances that the experimental weathering of minerals in through-flow reactors have the most relevance to natural weathering. There has been much debate concerning the nature of aqueous dissolution at the surface of the non-layer silicate primary rock-forming minerals. The pendulum has swung back and forth between incongruent and congruent dissolution; between the formation of a residual surface layer, (the thickness of which controls the rate of mineral dissolution) and dissolution virtually at the immediate mineral surface in the absence of such a residual layer; and between preferential dissolution at the sites of structural dislocations and defects and the lack of any relationship between the density of dislocations and the rates of dissolution. The current situation seems to be that, depending on the particular mineral being studied and the conditions of weathering, there are elements of truth in all these different interpretations. For olivines, pyroxenes and amphiboles, modern spectroscopic techniques seem to indicate that a cation-depleted layer does form during aqueous dissolution. Such a layer can 
also be observed during the dissolution of $\mathrm{Ca}$-rich plagioclase feldspars but its thickness is much reduced for the Na-rich and K-feldspars and it may not form at all where cations exceed protons in the weathering solutions. Thus, dissolution of these primary minerals can be congruent or incongruent, depending upon the conditions of weathering. Even where a residual layer is detected, it is still observed that the mineral surface is etched, implying preferential dissolution at selected points of weakness such as dislocations and defects. With regard to the relationship between dislocation densities (as revealed by etching) on mineral surfaces, and the dissolution rates of these surfaces, current evidence suggests that this may depend upon the saturation state of the weathering solutions. The widespread occurrence of microtextural features, such as exsolution lamellae of another phase, is another feature of the primary minerals that may control the progress of weathering. Where such lamellae are coherent with, and inherently more weatherable than, the host phase, as in the case of Ca-rich lamellae in plagioclase feldspars or Na-rich lamellae in K-feldspars, then they become the foci of preferential weathering.

Within the upper parts of the saprolite and in soils, the pyroxenes and amphiboles usually weather to a variety of clay minerals, the composition of which indicates inputs from sources other than the weathering primary mineral, admixed with $\mathrm{Fe}$ oxide minerals. Under more intensive weathering conditions, the primary mineral may decompose altogether, without formation of a weathering product. Halloysite and kaolinite, sometimes co-existing, are the most common weathering products of feldspars in soils and saprolites, but gibbsite is also found, sometimes during the early stages of weathering. Weathering in soils and, to some extent, in the upper parts of the saprolite may be mediated by the effects of organic acids, produced indirectly by the decomposition of organic matter or directly by the microbiota. The effect of organic acids at concentrations such as are found in soil waters on primary mineral dissolution, particularly the feldspars, does not appear to be as great as was once thought. There is certainly an enhancement over the effect of protons at $\mathrm{pH}$ values $>5$, but usually by less than an order of magnitude. At lower $\mathrm{pH}$ values, such an enhancement is very much lower, or even nonexistent. However, these conclusions do not necessarily apply to situations such as those in the rhizosphere where there is direct contact between minerals and organic acid excretions from roots, fungi or bacteria and where organic acid concentrations are higher. The recent suggestion that acidic mucopolysaccharides produced by bacteria are more effective agents of mineral weathering than organic acids remains to be comprehensively evaluated in natural weathering studies.

The decomposition of micas, particularly biotite, may progress to advanced stages even at the base of the weathering profile. Vermiculitization is the simplest form of weathering but, in addition to loss of interlayer $\mathrm{K}$, the process often involves oxidation of octahedral ferrous $\mathrm{Fe}$, ejection of $\mathrm{Fe}$ from the octahedral sheet leading to a more dioctahedral structure and development of a regularly interstratified structure. Oxidation may also increase the capacity of biotite to retain its interlayer $\mathrm{K}$, thus inhibiting the vermiculitization process. In these circumstances, biotite may weather directly to kaolinite, either through epitaxial growth or topotactic replacement, without going through a preliminary vermiculite phase. In soils, weathered biotite may consist of a multicomponent complex involving halloysite, goethite and gibbsite. Muscovite is much more resistant to weathering than biotite and is very difficult to vermiculitize, even in the laboratory. However, dioctahedral vermiculites are a common component of some soils and are likely to have formed from a dioctahedral muscovite-like precursor. Often, such vermiculites contain non-exchangeable hydroxy-Al interlayers in the interlamellar space and similar interlayers are also found in vermiculitized biotites. Like biotite, muscovite too can be converted to kaolinite in weathering profiles, apparently involving a solid-state replacement mechanism. Biotite can be vermiculitized by plants where it is the sole source of $\mathrm{K}$ and can be completely decomposed to an amorphous product by oxalic-acid producing fungi. The dissolution of biotite in mineral acids is incongruent over a wide $\mathrm{pH}$ range, with cations from the interlayer and the octahedral sheet being released before those of the tetrahedral sheet. On the other hand, muscovite has been found to dissolve congruently, but two orders of magnitude slower than biotite.

The weathering of chlorite also involves a process of vermiculitization, involving regular interstratification between chlorite and vermiculite layers, in weathered rock, saprolite and soil. Preferential dissolution of the brucite sheet 
following oxidation has been suggested as one mechanism by which this process occurs. With more intensive weathering, chlorite may weather to a mixture of halloysite and fine grained $\mathrm{Fe}$ oxide minerals, or may even decompose altogether. In mineral and organic acids, chlorite may decompose stoichiometrically, although dissolution has been found to be non-stoichiometric at low proton and ligand concentrations.

Finally, geochemists and soil scientists often regard the process of mineral weathering with different aims in mind and from widely differing perspectives. This review has attempted to bring together some of their more important findings in the context of the fully developed weathering profile, hopefully in a way that is both coherent and helpful in promoting further collaboration.

\section{REFERENCES}

Acker J.B. \& Bricker O.P. (1992) The influence of pH on biotite dissolution and alteration kinetics at low temperature. Geochimica et Cosmochimica Acta, 56, 3073-3092.

Adams W.A. (1976) Experimental evidence on the origin of vermiculite in soils on Lower Palaeozoic sediments. Soil Science Society of America Journal, 40, 793-795.

Adams W.A \& Kassim J.K. (1983) The origin of vermiculite in soils developed from Lower Palaeozoic sedimentary rocks in Mid-Wales. Soil Science Society of America Journal, 47, 316-320.

Ahn J.H. \& Peacor D.R. (1987) Kaolinization of biotite: TEM data and implications for an alteration mechanism. American Mineralogist, 72, 353-356.

Anand R.R. \& Gilkes R.J. (1984) Weathering of hornblende, plagioclase and chlorite in meta-dolerite, Australia. Geoderma, 34, 261-280.

Anand R.R., Gilkes R.J., Armitage T. \& Hillyer J. (1985) The influence of microenvironment on feldspar weathering in lateritic saprolite. Clays and Clay Minerals. 33, 31-46.

Anbeek C. (1992) The dependence of dissolution rates on grain size for some fresh and weathered feldspars. Geochimica et Cosmochimica Acta. 56, 3957-3970.

Anbeek C. (1993) The effect of natural weathering on dissolution rates. Geochimica et Cosmochimica Acta, 57, 4963-4975.

Aouidjit H., Elsass F., Righi D. \& Robert M. (1996) Mica weathering in acidic soils by analytical electron microscopy. Clay Minerals, 31, 319-332.

April R.H., Hluchy M.M. \& Newton R.M. (1986) The nature of vermiculite in Adirondack soils and till. Clays and Clay Minerals, 34, 549-556.

Aspandiar M.F \& Eggleton R.A. (2002a) Weathering of chlorite. I. Reactions and products in microsystems controlled by the primary mineral. Clays and Clay Minerals, 50, 685-698.

Aspandiar M.F. \& Eggleton R.A. (2002b) Weathering of chlorite. II. Reactions and products in microsystems controlled by the solution avenues. Clays and Clay Minerals, 50, 699-709.

Awad A., Koster van Groos A.F. \& Guggenheim S. (2000) Forsteritic olivine: Effect of crystallographic direction on dissolution kinetics. Geochimica et Cosmochimica Acta, 64, 1765-1772.

Bain D.C. (1977) The weathering of ferruginous chlorite in a podzol from Argyllshire, Scotland. Geoderma, 17, 193-208.

Bain D.C. \& Duthie D.M.L. (1984) The effect of weathering in the silt fractions on the apparent stability of chlorite in Scottish soil clays. Geoderma, 34, 221-227.

Bain D.C., Mellor A. \& Wilson M.J. (1990) Nature and origin of an aluminous vermiculitic weathering product in acid soils from upland catchments in Scotland. Clay Minerals, 25, 467-475.

Bain D.C., Mellor A., Wilson M.J. \& Duthie D.M.L. (1994) Chemical and mineralogical weathering rates and processes in an upland granitic till catchment in Scotland. Water, Air and Soil Pollution, 73, 11-27.

Banfield J.F. \& Barker W.W. (1994) Direct observation of reactant-product interfaces formed in natural weathering of exsolved defective amphibole to smectite: Evidence for episodic, isovolumetric reactions involving structural inheritance. Geochimica et Cosmochimica Acta, 58, 1419-1429.

Banfield J.F. \& Eggleton R.A. (1988) Transmission electron microscope study of biotite weathering. Clays and Clay Minerals, 36, 47-60.

Banfield J.F. \& Eggleton R.A. (1990) Analytical transmission electron microscope studies of plagioclase, muscovite and K-feldspar weathering. Clays and Clay Minerals, 38, 77-89.

Banfield J.F. \& Murakami T. (1998) Atomic resolution transmission electron microscope evidence for the mechanism by which chlorite weathers to $1: 1$ semiregular chlorite-vermiculite. American Mineralogist, 83, 348-357.

Banfield J.F., Veblen D.R. \& Jones B.F. (1990) Transmission electron microscopy of subsolidus oxidation and weathering of olivine. Contributions to Mineralogy and Petrology, 106, 110-123.

Banfield J.F, Jones B.F. \& Veblen D.R. (1991) An AEM-TEM study of weathering and diagenesis, Abert Lake, Oregon: I. Weathering reactions in the volcanics. Geochimica et Cosmochimica Acta, 55, 2781-2793.

Banfield J.F, Ferruzzi G.G., Casey W.H. \& Westrich H.R. (1995) HRTEM study comparing naturally and experimentally weathered pyroxenoids. Geochimica et Cosmochimica Acta, 59, 19-31. 
Banfield J.F., Barker W.W., Welch S.A. \& Taunton A. (1999) Biological impact on mineral dissolution: Application of the lichen model to understanding mineral weathering in the rhizosphere. Proceedings of the National Academy of Science, USA, 96, 3404-3411.

Barker W.W. \& Banfield J.F. (1996) Biologically versus inorganically mediated weathering reactions; relationships between minerals and extracellular microbial polymers in lithobiontic communities. Chemical Geology, 132, 55-69.

Barker W.W. \& Banfield J.F. (1998) Zones of chemical and physical interaction at interfaces between microbial communities and minerals; A model. Geomicrobiology Journal, 15, 223-244.

Barker W.W., Welch S.A., Chu S. \& Banfield J.F. (1998) Experimental observations on the effects of bacteria on aluminosilicate weathering. American Mineralogist, 83, 1551-1563.

Barnhisel R.I. \& Bertsch P.M. (1989) Chlorites and Hydroxy Interlayered Vermiculite and Smectite. Pp. 729-788 in: Minerals and Soil Environments (J.B. Dixon and S.B. Weed, editors). Published by the Soil Science Society of America, Madison, Wisconsin.

Barshad I. (1948) Vermiculite and its relation to biotite as revealed by base exchange reactions, X-ray analysis, differential thermal curves and water content. American Mineralogist, 33, 655-678.

Barshad I. \& Kishk F.M. (1968) Oxidation of ferrous iron in vermiculite and biotite alters fixation and replaceability of potassium. Science, 162, 1401-1402.

Basham I.R. (1974) Mineralogical changes associated with deep weathering of gabbro in Aberdeenshire. Clay Minerals, 10, 189-202.

Bassett W.A. (1960) Role of hydroxyl orientation in mica alteration. Geological Society of America Bulletin, 71, 449-456.

Berner R.A. (1991) A model of atmospheric $\mathrm{CO}_{2}$ over Phanerozoic time. American Journal of Science, 291, 339-376

Berner R.A. \& Holdren G.R. (1977) Mechanism of feldspar weathering: Some observational evidence. Geology, 5, 369-372.

Berner R.A. \& Holdren G.R. (1979) Mechanism of feldspar weathering - II. Observations of feldspars from soils. Geochimica et Cosmochimica Acta 43, 1173-1186.

Berner R.A. \& Schott J. (1982) Mechanism of pyroxene and amphibole weathering. II Observations of soil grains. American Journal of Science. 282, 1214-1231.

Berner R.A., Sjöberg E.L, Velbel M.A. \& Krom M.D. (1980) Dissolution of pyroxenes and amphiboles during weathering. Science, 207, 1205-1206.

Berner R.A., Hodren G.R. \& Schott J. (1985) Surface layers on dissolving silicates. (Comments on "Study of the weathering of albite at room temperature and pressure with a fluidised bed reactor" by L. Chou \& R. Wollast. Geochimica et Cosmochimica Acta, 49, $1657-1658$.

Blum A.E. \& Stillings L.L (1995) Feldspar dissolution kinetics. Pp. 291-351 in: Chemical Weathering Rates in Silicate Minerals (A.F. White and S.L. Brantley, editors). Reviews in Mineralogy, 31, Mineralogical Society of America, Washington, D.C. Blum A.E., Yund R.A. \& Lasaga A.C. (1990) The effect of dislocation density on the dissolution rate of quartz. Geochimica et Cosmochimica Acta, 54, 283-297.

Boyle J.R., Voigt G.K. \& Sawney B.L. (1967) Biotite flakes; alteration by chemical and biological treatment. Science, 155, 193-195.

Brady P.V., Dorn R.I., Brazel A.J., Clark J., Moore R.B. \& Glidewell T. (1999) Direct effects of lichen, rainfall and temperature on silicate weathering. Geochimica et Cosmochimica Acta, 63, 3293-3300.

Brantley S.L. \& Chen Y. (1995) Chemical weathering rates of pyroxenes and amphiboles. Pp. 119-172 in: Chemical Weathering Rates in Silicate Minerals (A.F. White and S.L. Brantley, editors). Reviews in Mineralogy, 31, Mineralogical Society of America, Washington, D.C.

Brantley S.R. \& Stillings L.L. (1996) Feldspar dissolution at $25^{\circ} \mathrm{C}$ and low pH. American Journal of Science, 296, 101-127.

Brown G. (1953) The dioctahedral analogue of vermiculite. Clay Minerals Bulletin, 2, 64-69.

Brown G. \& Stephen I. (1959) A structural study of iddingsite from New South Wales, Australia. American Mineralogist, 44, 251-260.

Carnicelli S., Mirabella A., Cecchini G. \& Sansi G. Weathering of chlorite to a low-charge expandable mineral in a Spodosol on the Appenine mountains, Italy. Clays and Clay Minerals, 45, 28-41.

Casey W.H., Westrich H.R., Arnold G.W. \& Banfield J.F. (1989) The surface chemistry of dissolving labradorite feldspar. Geochimica et Cosmochimica Acta, 53, 821-832.

Casey W.H., Carr M.J. \& Graham R.A. (1991a) Crystal defects and the dissolution kinetics of rutile. Geochimica et Cosmochimica Acta, 52, 1545-1556.

Casey W.H., Westrich H.R. \& Holdren G.R. (1991b) Dissolution rates of plagioclase at $\mathrm{pH}=2$ and 3 . American Mineralogist, 76, 211-217.

Casey W.H., Banfield J.F, Westrich H.R. \& McLaughlin L. (1993) What do dissolution experiments tell us about natural weathering? Chemical Geology, 105, $1-15$.

Cho H.D. \& Mermut A.R. (1992) Evidence for halloysite formation from weathering of ferruginous chlorite. Clays and Clay Minerals, 40, 608-619.

Chou L. \& Wollast R. (1984) Study of the weathering of albite at room temperature and pressure with a 
fluidised bed reactor. Geochimica et Cosmochimica Acta, 48, 2205-2217.

Chou L. \& Wollast R. (1985) Study of the weathering of albite at room temperature and pressure with a fluidised bed reactor. Reply to a comment by R.A. Berner, G.R. Holdren, Jr and J. Schott. Geochimica et Cosmochimica Acta, 49, 1659-1660.

Churchman G.J. (1978) Studies on a climax sequence in soils in tussock grasslands. Mineralogy. New Zealand Journal of Science, 21, 467-480.

Churchman G.J. (1980) Clay minerals formed from micas and chlorites in some New Zealand soils. Clay Minerals, 15, 59-76.

Cochran M.F. \& Berner R.A. (1996) Promotion of chemical weathering by higher plants: field observations on Hawaiian basalts. Chemical Geology, 132, $71-77$.

Coleman N.T., Le Roux F.H. \& Cady K.G. (1963) Biotite-hydrobiotite-vermiculite in soils. Nature, 198, 409-410.

Delvigne J.E. (1998) Atlas of Micromorphology of Mineral Alteration and Weathering. The Canadian Mineralogist, Special Publication No 3 . Mineralogical Association of Canada, $495 \mathrm{pp}$.

Delvigne J., Bisdom E.B.A, Sleeman J. \& Stoops G. (1979) Olivines, their pseudomorphs and secondary products. Pedologie, 29, 247-309.

Denison I.A., Fry W.H. \& Gile P.L. (1929) Alteration of muscovite and biotite in the soil. Technical Bulletin, No. 128. US Department of Agriculture, Washington, D.C.

De Kimpe C. \& Tardy Y. (1968) Etude de l'altération d'une biotite en kaolinite par spectroscopie infrarouge. Bulletin de Groupe français des Argiles, 19, $81-85$.

Dong H., Peacor D.R. \& Murphy S.F. (1998) TEM study of progressive alteration of igneous biotite to kaolinite throughout a weathered soil profile. Geochimica et Cosmochimica Acta, 62, 1881-1887.

Drever J.I. (1994) The effect of land plants on weathering rates of silicate minerals. Geochimica et Cosmochimica Acta, 58, 2325-2332.

Drever J.I. \& Stillings L.L. (1997) The role of organic acids in mineral weathering. Colloids and Surfaces. A. Physicochemical and Engineering Aspects, 120, $167-181$.

Eggleton R.A. (1975) Nontronite topotaxial after hedenbergite. American Mineralogist, 60, 1063-1068.

Eggleton R.A. (1984) Formation of iddingsite rims on olivine: a transmission electron microscope study. Clays and Clay Minerals, 32, 1-11.

Eggleton R.A. \& Boland J.N. (1982) Weathering of enstatite to talc through a sequence of transitional phases. Clays and Clay Minerals, 30, 11-20.

Eggleton R.A. \& Buseck P.R. (1980) High resolution electron microscopy of feldspar weathering. Clays and Clay Minerals, 28, 173-178.
Eswaran H. \& Bin W.C. (1978) A study of a deep weathering profile on granite in peninsular Malaysia. III. Alteration of feldspars. Soil Science Society of America Journal. 42, 154-158.

Eswaran H. \& Heng Y.Y. (1976) The weathering of biotite in a profile on gneiss in Malaysia. Geoderma, 16, 9-20.

Evans L.J. \& Adams W.A. (1975) Chlorite and illite in some Lower Palaeozoic mudstones of Mid-Wales. Clay Minerals, 10, 387-397.

Farmer V.C. \& Wilson M.J. (1970) Experimental conversion of biotite to hydrobiotite. Nature, 226, 841-842.

Farmer V.C, Russell J.D., McHardy W.J., Newman A.C.D., Ahlrichs J.L. \& Rimsaite J.H.Y. (1971) Evidence for loss of protons and octahedral iron from oxidised biotites and vermiculites. Mineralogical Magazine, 38, 121-137.

Fordham A.W. (1990a) Formation of trioctahedral illite from biotite in a soil profile over granite gneiss. Clays and Clay Minerals, 38, 187-195.

Fordham A.W. (1990b) Weathering of biotite into dioctahedral clay minerals. Clay Minerals, 25, $51-63$.

Franke W.A. \& Teschner-Steinhardt R. (1994) An experimental approach to the sequence of the stability of rock-forming minerals towards chemical stability. Catena, 21, 279-290.

Ghabru S.K., Mermut A.R. \& St Arnaud R.J. (1990) Isolation and characterization of an iron-rich chlorite-like mineral from soil clays. Soil Science Society of America Journal, 54, 281-287.

Gilkes R.J. (1973) The alteration products of potassium depleted oxybiotite. Clays and Clay Minerals, 21, 301-313.

Gilkes R.J. \& Little I.P. (1972) Weathering of chlorite and some associations of trace elements in Permian phyllites in southeast Queensland. Geoderma, 7, 233-247.

Gilkes R.J. \& Suddhiprakarn A. (1979a) Biotite alteration in deeply weathered granite. I. Morphological, mineralogical and chemical properties. Clays and Clay Minerals, 27, 349-360.

Gilkes R.J. \& Suddhiprakarn A. (1979b) Biotite alteration in deeply weathered granite. II. The oriented growth of secondary minerals. Clays and Clay Minerals, 27, 361-367.

Gilkes R.J., Young R.C. \& Quirk J.P. (1972) The oxidation of octahedral iron in biotite. Clays and Clay Minerals, 20, 303-315.

Gilkes R.J., Young R.C. \& Quirk J.P. (1973a) Artificial weathering of oxidised biotite: I. Potassium removal by sodium chloride and sodium tetraphenylboron solutions. Soil Science Society of America Journal, 37, 25-28.

Gilkes R.J., Young R.C. \& Quirk J.P. (1973b) Artificial weathering of oxidised biotite: II. Rates of dissolu- 
tion in $0.1,0.01$ and $0.001 M \mathrm{HCl}$. Soil Science Society of America Journal, 37, 29-33.

Goldich S.S. (1938) A study in rock weathering. Journal of Geology, 46, 17-58.

Grandstaff D.E. (1977) Some kinetics of bronzite orthopyroxene dissolution. Geochimica et Cosmochimica Acta, 41, 1097-1103.

Grandstaff D.E. (1978) Changes in surface area and morphology and the mechanism of forsterite dissolution. Geochimica et Cosmochimica Acta, 42, 1899-1901.

Hamer M., Graham R.C., Amrhein C. \& Bozhilov K.N. (2003) Dissolution of ripidolite (Mg,Fe-chlorite) in organic and inorganic acid solutions. Soil Science Society of America Journal, 67, 654-664.

Harris W.G., Zelazny L.W., Baker J.C. \& Martens D.C. (1985a) Biotite kaolinization in Virginia Piedmont soils: I. Extent, profile trends and grain morphological effects. Soil Science Society of America Journal, 49, 1290-1297.

Harris W.G., Zelazny L.W. \& Bloss F.D. (1985b) Biotite kaolinization in Virginia Piedmont soils: II. Zonation in single grains. Soil Science Society of America Journal, 49, 1297-1302.

Herbillon A.J. \& Makubi L. (1975) Weathering of chlorite in a soil derived from a chlorito-schist under humid tropical conditions. Geoderma, 13, 89-104.

Hettelingh J., Downing R. \& de Smet P. (1991) Mapping critical loads for Europe. CCE Technical Report No. 1, RIVM. Report No. 259101001, Co-ordination Center for Effects, RIVM.

Hochella M.F. \& Banfield J.F. (1996) Chemical weathering of silicates in nature: A microscopic perspective with theoretical considerations. Pp. 353-406 in: Chemical Weathering Rates in Silicate Minerals (A.F. White and S.L. Brantley, editors). Reviews in Mineralogy 31, Mineralogical Society of America, Washington, D.C.

Hoffland E., Giesler R., Jongmans T. \& van Breemen N. (2002) Increasing feldspar tunnelling by fungi across a north Sweden podzol chronosequence. Ecosystems, 5, $11-22$.

Holdren G.R. \& Berner R.A. (1979) Mechanism of feldspar weathering - I. Experimental studies. Geochimica et Cosmochimica Acta, 43, 1161-1171.

Holdren G.R and Speyer P.M. (1985) Reaction ratesurface area relationships during the early stages of weathering. I. Initial observations. Geochimica et Cosmochimica Acta, 49, 675-681.

Holdren G.R., Casey W.H., Westrich H.R., Carr M. \& Bosclough M. (1988) Bulk dislocation densities and dissolution rates in a calcic plagioclase feldspar. Chemical Geology, 70, 79.

Huang W.H. \& Keller W.D. (1970) Dissolution of rockforming minerals in organic acids: Simulated first stage weathering of fresh mineral surfaces. American Mineralogist, 55, 2076-2094.
Huang W.H. \& Kiang W.C. (1972) Laboratory dissolution of plagioclase in water and organic acids at room temperature. American Mineralogist, 57, 1849-1859.

Inskeep W.P., Nater E.A., Bloom P.R., Vandervoort D. \& Erich S.R. (1991) Characterization of laboratory weathered labradorite surfaces using X-ray photoelectron spectroscopy and transmission electron microscopy. Geochimica et Cosmochimica Acta, 55, 787-800.

Ismail F.T. (1969) Role of ferrous iron oxidation in the alteration of biotite and its effect on the type of clay minerals formed in soils of arid and humid regions. American Mineralogist, 54, 1460-1466.

Ismail F.T. (1970) Biotite weathering and clay formation in arid and humid regions, California. Soil Science, 109, 257-261.

Jenny H. (1941) Factors of Soil Formation: A System of Quantitative Pedology. McGraw Hill, New York, $281 \mathrm{pp}$.

Jeong G.Y. (1998) Vermicular kaolinite epitactic on primary phyllosilicates in the weathering profile of anorthsite. Clays and Clay Minerals, 46, 509-520.

Jeong G.Y. (2000) The dependence of localized crystallization of halloysite and kaolinite on primary minerals in the weathering profile of granite. Clays and Clay Minerals, 48, 196-203.

Jeong G.Y. \& Kim H.B. (2003) Mineralogy and chemistry of oxidized biotite in the weathering profile of granitic rocks. American Mineralogist, 88, 352-364.

Johnson L.J (1964) Occurrence of regularly interstratified chlorite vermiculite as a weathering product of chlorite in the soil. American Mineralogist, 49, 556-572.

Jolicoeur S., Ildefonse Ph. \& Bouchard M. (2000) Kaolinite and gibbsite weathering of biotite within saprolites and soils of central Virginia. Soil Science Society of America Journal, 64, 1118-1129.

Jones D., Wilson M.J. \& Tait J.M. (1980) Weathering of a basalt by Pertusaria, corallina. The Lichenologist, 12, 277-289.

Jones D., Wilson M.J and McHardy W.J. (1981) Lichen weathering of rock-forming minerals: application of scanning electron microscopy and microprobe analysis. Journal of Microscopy, 124, 95-104.

Jongmans A.G., Van Breemen N., Lundström. U.S., van Hees P.A.W., Finlay R.D., Srinivasam N., Unestam T., Giesler R., Melkerud P.-A. and Olsson M. (1997) Rock-eating fungi. Nature, 289, 682-683.

Kalinowski B.E. \& Scheda P. (1996) Kinetics of muscovite phlogopite and biotite dissolution and alteration at $\mathrm{pH} 1-4$, room remperature. Geochimica et Cosmochimica Acta, 60, 367-385.

Kapoor B.S. (1972) Weathering of micaceous clays in some Norwegian podzols. Clay Minerals, 9, $383-394$. 
Karathanasis A.D. (1988) Compositional and solubility relationships between aluminum hydroxy-interlayered soil smectites and vermiculites. Soil Science Society of America Journal, 52, 1500-1508.

Kato Y. (1965) Mineralogical study of weathering products of granodiorite at Shinshiro City, Japan. III. Weathering of primary minerals. (2) Mineralogical characteristics of weathered mineral grains. Soil Science and Plant Nutrition, 11, 30-40.

Kawano M. \& Tomita K. (1996) Amorphous aluminum hydroxide formed at the earliest weathering stages of K-feldspar. Clays and Clay Minerals, 44, 672-676.

Kirby S.H. \& Wegner M.W. (1978) Dislocation substructure of mantle-derived olivine as revealed by selective chemical etching and transmission electron microscopy. Physics and Chemistry of Minerals, 3, 309-330.

Kodama H., Schnitzer M. \& Jaakkimainen M. (1983) Chlorite and biotite weathering by fulvic acid solutions in closed and open systems. Candian Journal of Soil Science, 63, 619-629.

Kretzschmar R., Robarge W.P., Amoozegar A. \& Veprskas M.J. (1997) Biotite alteration to halloysite and kaolinite in soil-saprolite profiles developed from mica schist and granite gneiss. Geoderma, $\mathbf{7 5}$, $155-170$.

Landeweert R., Hoffland E., Finlay R.D., Kuyper T.W. \& van Breemen N. (2001) Linking plants to rocks: ectomucorrizhal fungi mobilize nutrients from minerals. Trends in Ecology and Evolution, 16, 248-254.

Lee M.R. \& Parsons I. (1995) Microtextural controls of weathering of perthitic alkali feldspars. Geochimica et Cosmochimica Acta, 59, 4465-4488.

Lee M.R. \& Parsons I. (1999) Biomechanical and biochemical weathering of lichen-encrusted granite: textural controls on organic-mineral interactions and deposition of silica-rich layers. Chemical Geology, 161, 385-397.

Lee M.R., Hodson M.E. \& Parsons I. (1998) The role of intergranular microtextures and microstructures in chemical and mechanical weathering: direct comparisons of experimentally and naturally weathered alkali feldspars. Geochimica et Cosmochimica Acta, 62, 2771-2788.

Leyval C. \& Berthelin J. (1991) Weathering of mica by roots and rhizospheric microorganisms. Soil Science Society of America Journal, 55, 1009-1016.

Luce R.W., Bartlett W.B. \& Parks G.A. (1972) Dissolution kinetics of magnesium silicates. Geochimica et Cosmochimica Acta, 36, 35-50.

Locke W.W. (1986) Rates of hornblende etching in soils on glacial deposits, Baffin Island, Canada. Pp. 129-145 in: Rates of Chemical Weathering of Rocks and Minerals (S.M. Colman and D.P. Dethier, editors). Academic Press, London, New York.
MacEwan D.M.C. (1954) "Cardenite', a trioctahdral montmorillonoid derived from biotite. Clay Minerals Bulletin, 2, 120-126.

Makumbi L. \& Herbillon A.K. (1972) Vermiculitisation experimentale d'une chlorite. Bulletin de Groupe français des Argiles, 24, 153-164.

Malmström M., Banwart S., Lewenhagen J., Duro L. \& Bruno J. (1996) The dissolution of biotite and chlorite at 25 degrees $\mathrm{C}$ in the near neutral $\mathrm{pH}$ region. Journal of Contaminant Hydrology, 21, 201-213.

Manley E.P. \& Evans L.J. (1986) Dissolution of feldspars by low molecular weight aliphatic and aromatic acids. Soil Science, 141, 106-112.

Martin H.W. \& Sparks D.L. (1985) On the behaviour of non-exchangeable potassium in soils. Communications in Soil Science and Plant Analysis, 16, 133-162.

Mast M.A. \& Drever J.I. (1986) The effect of oxalate on the dissolution rates of oligoclase and tremolite. Geochimica et Cosmochimica Acta, 51, 2559-2568.

Martin-Garcia J.M., Delgado G., Sández Maronón M., Párraga J.F. \& Delgado R. (1997) Nature of dioctahedral micas in Spanish red soils. Clay Minerals, 32, 107-122.

Mitsuda T. (1960) Pseudomorphs of kaolinite after biotite. Studies on mechanism of weathering; $1^{\text {st }}$ Report. Journal of the Faculty of Science, Hokkaido University, Series IV. Geology and Mineralogy, 10, 481-494.

Mogk D.W. \& Locke W.W. III (1988) Application of Auger Electron Spectroscopy (AES) to naturally weathered hornblende. Geochimica et Cosmochimica Acta, 52, 2537-2542.

Mojalalli M. \& Weed S.B. (1978) Weathering of micas by mycorrizhal soybean plants. Soil Science Society of America Proceedings, 42, 367-372.

Moon H.S., Song Y. \& Lee S.Y. (1994) Supergene vermiculitization of phlogopite and biotite in ultramafic and mafic rocks, central Korea. Clays and Clay Minerals, 42, 259-268.

Mortland M.M. \& Lawton K. (1961) Relationships between particle size and potassium release from biotite and its analogues. Soil Science Society of America Proceedings, 25, 473-476.

Mortland M.M., Lawton K. \& Uehara G. (1956) Alteration of biotite to vermiculite by plant growth. Soil Science, 82, 477-481.

Moulton K.L., West J. \& Berner R.A. (2000) Solute flux and mineral mass balances approaches to the quantification of plant effects on silicate weathering. American Journal of Science, 300, 539-570.

Muir I.J., Bancroft M.G. \& Nesbitt H.W. (1989) Characteristics of altered labradorite surfaces by SIMS and XPS. Geochimica et Cosmochimica Acta, 53, 1235-1241.

Muir I.J., Bancroft M.G., Shotyk \& Nesbitt H.W. (1990) 
A SIMS and XPS study of dissolving plagioclase. Geochimica et Cosmochimica Acta, 54, 2247-2256.

Murakami T., Isobe H., Sato T. \& Ohnuki T. (1996) Weathering of chlorite in a quartz-chlorite schist. I. Mineralogical and chemical changes. Clays and Clay Minerals, 44, 244-256.

Nahon D.B. \& Colin F. (1982) Chemical weathering of orthopyroxenes under lateritic conditions. American Journal of Science, 282, 1232-1245.

Nahon D., Colin F. \& Tardy Y. (1982) Formation and distribution of $\mathrm{Mg}, \mathrm{Fe}, \mathrm{Mn}$-smectites in the first stages of the lateritic weathering of forsterite and tephroite. Clay Minerals, 17, 339-348.

Nesbitt H.W. \& Muir I.J. (1988) SIMS depth profiles of weathered plagioclase and processes affecting dissolved $\mathrm{Al}$ and $\mathrm{Si}$ in some acidic soil solutions. Nature, 334, 336-338.

Nesbitt H.W., Macrae N.D. \& Shotyk W. (1991) Congruent and incongruent dissolution of labradorite in dilute acidic salt solutions. Journal of Geology, 99, 429-442.

Newman A.C.D. (1969) Cation exchange properties of micas. I. The relation between mica composition and $\mathrm{K}$-exchange in solutions of different $\mathrm{pH}$. Journal of Soil Science, 20, 357-373.

Newman A.C.D. \& Brown G. (1966) Chemical changes during the alteration of micas. Clay Minerals, 6, 297-309.

Nilsson J. \& Grennfelt P. (1988) Critical Loads for Sulphur and Nitrogen. Nordic Council of Ministers. Nord. 1988, 15.

Norrish K. (1973) Factors in the weathering of vermiculite. Proceedings of the International Clay Conference, Madrid (J. M. Serratosa, editor). CSIC, Madrid, pp. 419-432.

Nugent M.A., Brantley S.L., Pantano C.G. \& Maurice P.A (1998) The influence of natural mineral coatings on feldspar weathering. Nature, 395, 588-591.

Oxburgh R., Drever J.I. \& Sun Y.T. (1994) Mechanism of plagioclase dissolution in acid solution at $25^{\circ} \mathrm{C}$. Geochimica et Cosmochimica Acta, 58, 661-669.

Parham W.P. (1969a) Halloysite-rich tropical weathering products of Hong Kong. Proceedings of the International Clay Conference, Tokyo I, 431-440.

Parham W.P. (1969b) Formation of halloysite from feldspar: low temperature artificial weathering versus natural weathering. Clays and Clay Minerals, 17, 13-22.

Petit J.C. Della Mea G., Dran J.C., Schott J. \& Berner R.A. (1987) Mechanism of diopside dissolution from hydrogen depth profiling. Nature, 325, 705-707.

Petrovic R., Berner R.A. \& Goldhaber M.B. (1976) Rate control in dissolution of alkali feldspars-I. Study of residual feldspar grains by X-ray photoelectron spectroscopy. Geochimica et Cosmochimica Acta, 40, 537-548.

Pokrovsky O.S. \& Schott J. (2000a) Forsteritic surface composition in aqueous solutions: A combined potentiometric, electrokinetic and spectroscopic approach. Geochimica et Cosmochimica Acta, 64, 3299-3312.

Pokrovsky O.S. \& Schott J. (2000b) Kinetics and mechanism of forsterite dissolution at $25^{\circ} \mathrm{C}$ and $\mathrm{pH}$ from 1 to 12. Geochimica et Cosmochimica Acta, 64, $3313-3325$.

Proust D. (1982) Supergene alteration of hornblende in an amphibolite from Massif Central, France. Proceedings of the International Clay Conference, 1981 (H. van Olphen and F. Veniale, editors), pp. 357-364.

Proust D., Eymery J.D. \& Beaufort D. (1986) Supergene vermiculitization of a magnesian chlorite; iron and magnesium removal processes. Clays and Clay Minerals, 34, 572-580.

Prudêncao M.I., Sequeira-Braga M.A., Paquet H., Warenborgh J.C., Pereira L.C.J. and Gouveia M.A. (2002) Clay mineral assemblages in weathered basalt profiles from central and southern Portugal: Climatic significance. Catena, 49, 77-89.

Purvis O.W. (1984) The occurrence of copper oxalate in lichens growing on copper sulphide-bearing rocks in Scandinavia. The Lichenologist, 16, 197-204.

Raman K.V. \& Jackson M.L. (1965) Mica surface morphology changes during weathering. Soil Science Society of America Proceedings, 29, 29-32.

Rausell-Colom J.A., Sweatman T.R., Wells C.B. \& Norrish K. (1964) Studies in the artificial weathering of mica. Pp. 40-72 in: Experimental Pedology. Butterworths, London.

Rebertus R.A., Weed S.B. \& Buol S.W. (1986) Transformations of biotite to kaolinite during saprolite-soil weathering. Soil Science Society of America Journal, 50, 810-819.

Reed M.G. \& Scott A.D. (1962) Chemical extraction of potassium from soils and micaceous minerals with solutions containing tetraphenyboron. II. Biotite. Soil Science Society of America Proceedings, 26, 41-45.

Reichenbach H. Graf von \& Rich C.I. (1969) Potassium release from muscovite as influenced by particle size. Clays and Clay Minerals, 17, 23-29.

Robert M., Hardy M. \& Elsass F. (1991) Crystallochemistry, properties and organization of soil clays derived from major saedimentary rocks in France. Clay Minerals, 26, 409-420.

Robertson I.D.M. \& Eggleton R.A. (1991) Weathering of granitic muscovite to kaolinite and halloysite and of plagioclase-derived kaolinite to halloysite. Clays and Clay Minerals, 39, 113-126.

Rodgers G.P. \& Holland H.D. (1979) Weathering products in microcracks in feldspars. Geology, 7, $278-280$.

Romero R., Robert M., Elsass F. \& Garcia C. (1992) Evidence by transmission electron microscopy of weathering microsystems in soils developed from 
crystalline rocks. Clay Minerals, 27, 21-34.

Ross G.J. (1968) Structural decomposition of an orthochlorite during its acid dissolution. The Canadian Mineralogist, 9, 522-530.

Ross G.J. (1969) Acid dissolution of chlorites; release of magnesium, iron, aluminum and mode of acid attack. Clays and Clay Minerals, 17, 347-354.

Ross G.J. \& Kodama H. (1976) Experimental alteration of a chlorite into a regularly interstratified chloritevermiculite by chemical oxidation. Clays and Clay Minerals, 24, 183-190.

Ross G.J. \& Kodama H. (1976) Experimental transformation of a chlorite into a vermiculite. Clays and Clay Minerals, 22, 205-211.

Ross G.J., Wang C., Ozkan A.I. \& Rees H.W. (1982) Weathering of chlorite and mica in a New Brunswick podzol developed on till derived from chlorite-mica schist. Geoderma, 27, 255-267.

Ruiz Cruz M.D. (1999) New data for metamorphic vermiculite. European Journal of Mineralogy, 11, $533-548$.

Schott J. \& Berner R.A. (1983) X-ray photoelectron studies of the mechanism of iron silicate dissolution during weathering. Geochimica et Cosmochimica Acta, 47, 2233-2240.

Schott J., Berner R.A. \& Sjöberg E.L. (1981) Mechanism of pyroxene and amphibole weathering. I. Experimental studies of iron-free minerals. Geochimica et Cosmochimica Acta, 45, 2123-2135.

Schott J., Brantley S.L., Crerar D., Guy C., Borcsik M. \& Willaime C. (1989) Dissolution kinetics of strained calcite. Geochimica et Cosmochimica Acta, 53, 373-382.

Scott A.D. \& Amonette J. (1988) Role of iron in mica weathering. Pp. 537-623 in: Iron in Soils and Clay Minerals (J.W. Stucki, B.A. Goodman and U. Schwertmann, editors). NATO ASI Series C: Mathematical and Physical Sciences. D. Reidel Publishing Company, Dordrecht, The Netherlands.

Scott A.D and Smith S.J. (1966) Susceptibility of interlayer potassium in micas to exchange with sodium. Clays and Clay Minerals, 14, 69-81.

Senkayi A.L., Dixon J.B. \& Hossner J.R. (1981) Transformation of chlorite to smectite through regularly interstratified intermediates. Soil Science Society of America Journal, 45, 650-656.

Shau Y.H., Peacor D.R. \& Essene E.J. (1990) Corrensite and mixed layer chlorite corrensite in metabasalt from northern Taiwan; TEM, AEM EMPA, XRD and optical studies. Contributions to Mineralogy and Petrology, 105, 123-142.

Siever R. \& Woodford N. (1979) Dissolution kinetics and the weathering of mafic minerals. Geochimica et Cosmochimica Acta, 43, 717-724.

Singh B. \& Gilkes R.J. (1991) Weathering of a chromium muscovite to kaolinite. Clays and Clay Minerals, 39, 571-579.
Singh B. \& Gilkes R.J. (1993) Weathering of spodumene to smectite in a lateritic environment. Clays and Clay Minerals, 41, 624-630.

Smith K.L., Milnes A.R. \& Eggleton R.A. (1987) Weathering of basalt, formation of iddingsite. Clays and Clay Minerals, 36, 418-428.

Spyridakis D.E., Chesters G. \& Wilde S.A. (1967) Kaolinisation of biotite as a result of coniferous and deciduous seedling growth. Soil Science Society of America Proceedings, 31, 203-210.

Stillings L.L. \& Brantley S.L. (1995) Feldspar dissolution at $25^{\circ} \mathrm{C}$ and $\mathrm{pH} 3$ : Reaction stoichiometry and the effect of cations. Geochimica et Cosmochimica Acta, 59, 1483-1496.

Stillings L.L, Drever J.I., Brantley S.L., Sun Y. \& Oxburgh R. (1996) Rates of feldspar dissolution at $\mathrm{pH} 3-7$ with $0-8 \mathrm{mM}$ oxalic acid. Chemical Geology, 132, 79-89.

Sverdrup H. \& Warfvinge P. (1990) The role of weathering and forestry in determining the acidity of lakes in Sweden. Water, Air and Soil Pollution, 52, 71-78.

Sverdrup H. de Vries W. \& Henriksen A. (1990) Mapping critical loads. Miljørapport 1990, 14. Nordic Council of Ministers, Copenhagen.

Sverdrup H., Warfvinge P. \& Nihlgård B. (1994) Assessment of soil acidification effects on forest growth in Sweden. Water, Air and Soil Pollution, 78, $1-36$.

Tazaki K. (1976) Scanning electron microscopic study of formation of gibbsite from plagioclase. Papers of the Institute for Thermal Springs Research, No 45, $11-24$.

Tazaki K. \& Fyfe W.S. (1987) Primitive clay precursors formed on feldspar. Canadian Journal of Earth Sciences, 24, 506-527.

Teng H.H. (2004) Controls by saturation state on etch pit formation during calcite dissolution. Geochimica et Cosmochimica Acta, 68, 253-262.

Teng H.H., Fenter P., Cheng L. \& Sturchio N.C. (2001) Resolving orthoclase dissolution processes with atomic force microscopy and X-ray reflectivity. Geochimica et Cosmochimica Acta, 65, 3459-3474.

Tomita K. (1977) Experimental transformation of $2 \mathrm{M}$ sericite into a rectorite-type mixed-layer mineral by treatment with various salts. Clays and Clay Minerals, 25, 302-308.

Tsuzuki Y., Nagasawa K. \& Isobe K. (1968) Weathered biotite from Matsusaka, central Japan. Mineralogical Journal, 5, 365-382.

Turpault M.P. \& Trotignon L. (1994) The dissolution of biotite single crystals in dilute $\mathrm{HNO}_{3}$ at $24^{\circ} \mathrm{C}$; Evidence of an anisotropic corrosion process of micas in acidic solutions. Geochimica et Cosmochimica Acta, 58, 2761-2775.

Van Breemen N., Finlay R.D., Lundström U.S., Jongmans A.G., Giesler R. \& Melkerud P.-A. 
(2000) Mycorrhizal weathering: a true case of mineral plant nutrition? Biogeochemistry, 49, 53-67.

Van Hees P.A.W., Lundström U.S. \& Mörth C.M. (2002) Dissolution of microcline and labradorite in a forest $\mathrm{O}$ horizon extract: the effect of naturally occurring organic acids. Chemical Geology, 189, 199-211.

Varadachari C., Barman A.K. \& Ghosh K. (1994) Weathering of silicate minerals by organic acids. II Nature of residual products. Geoderma, 61, 251-268.

Velbel M.A. (1985) Geochemical mass balances and weathering rates in forested watersheds of the southern Blue Ridge. American Journal of Science, 285, 904-930.

Velbel M.A. (1989) Weathering of hornblende to ferruginous products by a dissolution-reprecipitation mechanism: petrography and stoichiometry. Clays and Clay Minerals, 37, 515-524.

Violante P. \& Wilson M.J. (1983) Mineralogy of some Italian Andosols with special reference to the origin of the clay fraction. Geoderma, 29, 157-174.

Walker G.F. (1949) The decomposition of biotite in the soil. Mineralogical Magazine, 28, 693-703.

Walker J.C.G., Hays P.B. \& Kasting, J.F. (1981) A negative feedback mechanism for the long-term stabilisation of the Earth's surface temperature. Journal of Geophysical Research, 86, 9776-9782.

Wallander H. (2000) Use of strontium isotopes and foliar $\mathrm{K}$ content to estimate weathering of biotite induced by pine seedlings colonised by ectomycorrhizal fungi from two different soils. Plant and Soil, 222, 215-219.

Wallander H. \& Wickman T. (1999) Biotite and microcline as potassium sources in ectomycorrhizal and non-mycorrhizal Pinus sylvestris seedlings. Mycorrhiza, 9, 25-32.

Weed S.B., Davey C.B. \& Cook M.G. (1969) Weathering of micas by fungi. Soil Science Society of America Proceedings, 33, 702-706.

Welch S.S. \& Ullman W.J. (1993) The effect of organic acids on plagioclase dissolution rates and stoichiometry. Geochimica et Cosmochimica Acta, 57, 2725-2737.

Welch S.A. \& Banfield J.F. (2002) Modification of olivine surface morphology and reactivity by microbial activity during microbial weathering. Geochimica et Cosmochimica Acta, 66, 213-221.

Welch S.A., Barker W.W. \& Banfield J.F. (1999) Microbial extracellular polysaccharides and plagio- clase dissolution. Geochimica et Cosmochimica Acta, 63, 1405-1419.

Wilson M.J. (1966) The weathering of biotite in some Aberdeenshire soils. Mineralogical Magazine, 35, $1080-1093$.

Wilson M.J. (1969) A gibbsitic soil derived from the weathering of an ultrabasic rock on the island of Rhum. Scottish Journal of Geology, 5, 81-89.

Wilson M.J. (1970) A study of rock weathering in a soil derived from a biotite-hornblende rock. I. Weathering of biotite. Clay Minerals, 8, 291-303.

Wilson M.J. (1975) Chemical weathering of some primary rock-forming minerals. Soil Science, 119, 349-345.

Wilson M.J. (2004) Weathering of rocks by lichens with special reference to stonework: a review. Land Reconstruction and Management, 3, 51-60.

Wilson M.J. \& Duthie D.M.L. (1981) Some aspects of interstratal alteration of biotite in Old Red Sandstone. Scottish Journal of Geology, 17, 65-72.

Wilson M.J. \& Farmer V.C. (1970) A study of weathering in a soil derived from a biotite-hornblende rock. II Weathering of hornblende. Clay Minerals, 8, 435-444.

Wilson M.J. \& Jones D. (1983) Lichen weathering of minerals: Implications for pedogenesis. In "Residual Deposits: Surface Related Weathering Processes and Materials. "Special issue of the Journal of the Geological Society, 5-12.

Wilson M.J. \& Jones D. (1984) The occurrence and significance of manganese oxalate in Pertusaria corallina (Lichenes). Pedobiologia, 26, 373-379.

Wilson M.J. \& McHardy W.J. (1980) Experimental etching of a microcline-perthite and implications concerning natural weathering. Journal of Microscopy, 120, 291-302.

Wilson M.J., Bain D.C. \& McHardy W.J. (1971) Clay mineral formation in a deeply weathered boulder conglomerate in north east Scotland. Clays and Clay Minerals, 19, 345-352.

Wilson M.J., Jones D. \& McHardy W.J. (1981) The weathering of serpentinite by Lecanora atra. The Lichenologist, 13, 167-176.

Wollast R. (1967) Kinetics of the alteration of Kfeldspar in buffered solutions at low temperature. Geochimica et Cosmochimica Acta, 31, 635-548.

Zhang H., Bloom P.R. \& Nater E.A. (1993) Change in surface area and dissolution rates during hornblende dissolution at $\mathrm{pH}$ 4.0. Geochimica et Cosmochimica Acta, 57, 1681-1689. 